\title{
The Transformation of Work and the Law of
}

\section{Workplace Accidents, 1842-1910}

\author{
John Fabian Witt
}

The common law rules of fellow servant, assumption of risk, and contributory negligence posed a series of daunting obstacles for nineteenthcentury workers seeking to recover for injuries suffered on the job. Strong opposition to the "unholy trinity" of the common law's workplace accident regime began to develop among progressive reformers in the first decade of the twentieth century. In 1910, New York State enacted the first modern workmen's ${ }^{2}$ compensation law in the United States, providing compensation to injured workers and their families without regard to fault. ${ }^{3}$ By the end of the decade an astounding thirty-nine states, the District of Columbia, and three U.S. territories had followed New York's lead. ${ }^{4}$

The transformation of work accident law has been the subject of a large and sometimes contentious scholarship among historians, lawyers, and social scientists. ${ }^{5}$ Scholars have generally been inattentive, however, to the ways in

1. William Prosser, Handbook of the LaW of Torts 512 (1941).

2. This Note retains the gender-specific terminology used by contemporaries to describe no-fault workplace accident laws in order to avoid anachronism. Indeed, the Note seeks (if only in passing) to touch on ways in which the gendered notion of "manliness" and its relation to work played an important role in the law and culture of work accidents.

3. See An Act To Amend the Labor Law, in Relation to Workmen's Compensation in Certain Dangerous Employments, ch. 674, 1910 N.Y. Laws 1945. The New York Court of Appeals struck down the New York legislation in Ives v. South Buffalo Railroad, 94 N.E. 431,448 (N.Y. 1911) (Werner, J.), but the legislature reenacted a revised compensation statute after the ratification of a constitutional amendment, see Workmen's Compensation Law, ch. 816, 1913 N.Y. Laws 2277.

4. See Harry Weiss, Employers' Liability and Workmen's Compensation, in 3 JoHn R. Commons ET AL., HiSTORY OF LABOR IN THE UNITED STATES 564, 575-76 (1935).

5. See, e.g., EdWARd D. BERKOWITZ \& Kim MCQUaID, CREATING THE WElfare STATE 43-46 (rev. ed. 1992) (arguing that workmen's compensation represented a compromise between labor and capital that was considered to be in both sides' interest); GUIDO CALABRESI, THE COSTS OF ACCIDENTS 245-46 (1970) (discussing workmen's compensation as the beginning of modern strict liability in the law of torts); RICHARD HOFSTADTER, THE AGE OF REFORM 242 (1955) (explaining workmen's compensation as an example of professional-class status anxiety in an age of corporate consolidation); MICHAEL KATZ, IN THE SHADOW OF THE POORHOUSE 191-95 (1986) (describing workmen's compensation as a "lame attempt" to solve the problem of industrial accident liability that nonetheless set important precedents for subsequent welfare state programs); RoY LUBOVE, THE STRUGGLE FOR SOCIAL SECURITY, 1900-1935, at 45-65 (2d ed. 1986) (describing workmen's compensation as the earliest embodiment of a weak American welfare state); THEDA SKOCPOL, PROTECTING SOldiERS AND MOTHERS 285-98 (1992) (explaining workmen's compensation as an isolated exception to the prevailing early 20th-century resistance to social insurance legislation that encompassed male workers); James Weinstein, Big Business and the Origins of Workmen's Compensation, 8 LAB. HIST. 156, 159-60 (1967) (arguing that workmen's compensation was a central episode in capitalism's 20th-century project of corporate-liberal hegemony cloaked as humanitarian reform). 
which the transformation of the law of work accidents reflected and gave shape to an important shift in the ways in which Americans thought about and organized work itself. This Note argues that the nineteenth-century law of workplace accidents is perhaps best understood by reference to what historian Daniel Rodgers has described as nineteenth-century Americans' 'moral preoccupation with labor." 6

The nineteenth-century work ethic contained within itself a critical ambiguity. For even as the work ethic could sustain ideas about the dignity of work and the moral value of labor, it could also serve the economic interests of employers seeking to create a disciplined and industrious workforce. The contention of Part I of this Note is that the common law of work accidents captured the deep ambiguities of the nineteenth-century work ethic. In many instances, nineteenth-century work accident law cynically deployed notions of the value of worker responsibility and self-reliance in such a way as to obscure employer power and enforce employee discipline in the workplace. Yet the common law of work accidents also embodied a limited conception of managerial control over the processes of production and created a legal regime that may even have protected the persistence of informal worker discretion over the processes of production. Workmen's compensation reform on the other hand-to which the Note turns in Part II-at once responded to and accelerated the dramatically expanded managerial control of the workplace represented by the scientific management revolution of the first decade of the twentieth century. In one sense, workmen's compensation's commitment to bringing at least an element of public control into the private power structure of the employment relation represented an opportunity to reconstruct a democratic governance of work. As we shall see, however, most supporters of workmen's compensation sought not so much to democratize the work relation as to realize the potential of expert managerial administration of work.

For those who had sought to uphold the dignity of meaningful work, then, workmen's compensation signaled and gave shape to a crisis for the nineteenth-century work ethic: In a world in which managers controlled even the details of production, it was no longer clear that labor could meaningfully be said to do any moral work. This new organization of work posed particularly acute difficulties for the skilled industrial craftsmen who formed the heart of the late nineteenth-century labor movement, and Part III describes the ambiguities of these workers' hesitant but ultimate acceptance of workmen's compensation. In conclusion, the Note turns to a little-known 1910 proposal by Louis D. Brandeis for special juries of workmen to resolve work accident cases. For those, like Brandeis, who believed that self-governance in work was critical to sustaining self-governance in politics, the abandonment of

6. DANiel T. Rodgers, THE Work EthiC IN INDUSTRIAL AMERICA, 1850-1920, at 17 (1978). 
the connection between work and moral virtue required the reconstruction of a link between self-direction at work and political self-governance.

\section{The LaW of Industrial Accidents in the NineteEnTH Century}

\section{A. The Rule of Farwell}

Chief Justice Lemuel Shaw of the Massachusetts Supreme Court set the path for the American common law of workplace accidents in the 1842 case of Farwell v. Boston \& Worcester Rail Road. ${ }^{7}$ Farwell, an engineer, sought recovery for injuries sustained when his train was derailed by a switch left negligently across the tracks by a switchman. ${ }^{8}$ Shaw ruled that the liability of an employer to his employee was to be determined by reference to the private agreement of the parties. ${ }^{9}$ In the absence of an employer-employee agreement on who was to bear the cost of work accidents, Shaw continued, considerations of "justice" and "policy" impelled courts to infer that the employee assumed all ordinary risks incident to employment. ${ }^{10}$ Unlike the passenger, who did not contract to assume the risks of passage, the worker was in a better position than the employer to reduce the risk of accidents. " Thus, absent indications to the contrary, the worker would be presumed to have assumed the risks of injury due to the negligence of a fellow servant. ${ }^{12}$

Shaw's decision in Farwell proved to be enormously influential among nineteenth-century judges. With only a few isolated exceptions, the fellow servant doctrine and its analog rule, assumption of risk, quickly became the foundation of the common law approach to workplace accidents. ${ }^{13}$ Historians,

7. 45 Mass. (4 Met.) 49 (1842). The first recorded common law case of an employee bringing a claim against an employer for injuries suffered in the course of employment was the English case of Priestley v. Fowler, 150 Eng. Rep. 1030 (Ex. 1837), in which the court rejected the claim of a butcher boy injured by the overturning of his master's cart. See A.W. BRIAN SIMPSON, LEADING CASES IN THE COMMON LAW 100-34 (1995); see also R.W. KOSTAL, LAW AND ENGLISH RAILWAY CAPITALISM 1825-1875, at 257-79 (rev. ed. 1997). In 1841, the Supreme Court of South Carolina held that a railroad fireman could not recover from his employer for damages incurred because of the negligence of a fellow servant. See Murray v. South Carolina R.R., 26 S.C.L. (1 McMul.) 385 (1841). The court was split, however, and subsequent cases in other jurisdictions relied on Farwell rather than Murray.

8. See Farwell, 45 Mass. (4 Met.) at 50.

9. See id. at 56.

10. Id. at 57. As Shaw stated,

The general rule, resulting from considerations as well of justice as of policy, is, that he who engages in the employment of another for the performance of specified duties and services, for compensation, takes upon himself the natural and ordinary risks and perils incident to the performance of such services, and in legal presumption the compensation is adjusted Id. accordingly.

11. See id. at 57-59. It is significant that in setting this general default rule Shaw showed little interest in the actual sociology of the workplace, let alone the probability of considerable variation from one workplace to another in workers' capacity to prevent accidents.

12. See id. at 59.

13. See Comment, The Creation of a Common Law Rule: The Fellow Servant Rule, 1837-1860, 132 U. PA. L. REV. 579, 594-600 (1984). 
however, have been highly critical of the fellow servant doctrine. According to the classic view, the rule represented a judicially enacted subsidy to emerging industries at the expense of workers. ${ }^{14}$ More recently, labor law historian Christopher Tomlins has argued that the fellow servant doctrine was complicit in the construction of a hierarchical relationship between employer and employee in the emerging industrial workplace. ${ }^{15}$ On this view, the rule of fellow servant legitimated employer control in the workplace by insulating inequalities in the industrial workplace from public control.

These critical interpretations bear important truths. Shaw's refusal to inject public norms into the private contractual relationship of employee and employer insulated the power disparity between employer and employee from public intervention; moreover, the common law rules did relieve industries of the cost of compulsory payment for most of their workers' injuries. But such interpretations are, in important respects, incomplete. Perhaps more than anything else, the common law rules reflected a nineteenth-century way of thinking about and organizing work, the ambivalences of which lend somewhat more ambiguity to the common law regime than these views allow.

\section{B. Work and Citizenship in Nineteenth-Century America}

\section{Ideology, Work, and Citizenship}

For the skilled craftsmen and middling classes of nineteenth-century America, dignity and self-discipline in productive labor represented one of the

14. See Lawrence M. Friedman \& Jack Ladinsky, Social Change and the Law of Industrial Accidents, 67 Colum. L. REV. 50, 58 (1967); see also LEONARD W. LEVy, THE LAW OF THE CommonWEALTH AND CHIEF JUSTICE SHAW 166 (1957) (observing that at "a critical stage" in the development of American capitalism, the fellow servant doctrine relieved industry "of an enormous financial burden"); $c f$. MORTON J. HoRWITZ, THE TRANSFORMATION OF AMERICAN LAW, 1780-1860, at 210 (1977) (arguing that the fellow servant doctrine "ratif[ied] those forms of inequality that the market system produced"). The difficulty with the subsidy thesis is not, as law and economics scholars have argued, that the rules of fellow servant were in fact efficient, see, e.g., Richard A. Posner, A Theory of Negligence, 1 J. LEGAL STUD. 29, 44-45 (1972), or even that they were efficient with respect to the railroad industry, see Gary T. Schwartz, The Character of Early American Tort Law, 36 UCLA L. REV. 641, 709-12 (1989). Instead, the problem with the subsidy thesis is that it is impossible to deduce particular legal doctrines from the general abstraction of the "needs" of an expanding market economy. See Robert W. Gordon, Critical Legal Histories, 36 STAN. L. REV. 57, $75-78$ (1984). For accounts that look to ideological factors to explain the common law workplace accident cases, see Alfred S. Konefsky, "As Best To Subserve Their Own Interests": Lemuel Shaw, Labor Conspiracy, and Fellow Servants, 7 LAW \& HIST. REV. 219, 229-35 (1989); and Comment, supra note 13, at 594-600. For an important recent reinterpretation, see SIMPSON, supra note 7, at 127, which argues that the early common law work accident cases represented a critical "first step towards a world in which tort law became a candidate for the job of replacing the older mechanisms of support" such as a master's obligation to care for domestic servants or the parish's responsibility to care for the sick or injured poor.

15. See CHRISTOPHER L. TOMLINS, LAW, LABOR, AND IDEOLOGY IN THE EARLY AMERICAN REPUBLIC 306-84 (1993); see also KAREN ORREN, BELATED FEUDALISM 107-08 (1991) (arguing that the fellow servant doctrine organized the law of workplace accidents around a model of status relations rather than contract relations). 
critical components of the moral foundation of a self-governing citizenry. ${ }^{16}$ There were, of course, sharp differences of opinion over how work contributed to moral virtue and over what kind of work was required to sustain such virtue. For the skilled artisan craftsmen who held on to the republicanism of the late eighteenth century, preservation of republican self-government rested on citizens' ownership of the means of the production; only the economically independent producer would be free of the relationships of dependence that threatened to corrupt virtuous self-government. ${ }^{17}$ Among elites, a different, narrower conception of free labor began to emerge in the years before the Civil War. On this view-which bore important traces of classical political economy and of the Enlightenment idea of possessive individualism ${ }^{18}$ - the status of wage earner rather than independent owner-producer was sufficient to sustain a narrowed conception of the relationship between work and virtue. ${ }^{19}$

Yet for all the internal divisions within the nineteenth-century ethic of free labor, many of the competing conceptions of free labor shared a rhetorical commitment to the dignity and importance of work. Skilled workers and elites alike argued that a worker's skill and his exercise of judgment and discretion over work processes served an educative function, training citizens for the work of self-government by their participation in the governance of work processes. For English immigrant and mechanic Timothy Claxton in the 1830s, as for Brotherhood of Locomotive Firemen leader and editor William Sayre in the 1870s, dignified and productive labor served as the foundation of personal and national virtue. ${ }^{20}$ Similarly, middle-class reformers such as New York Tribune editor Horace Greeley and Unitarian William Ellery Channing believed that the processes of labor were closely linked to the "mental development and

16. See LeON Fink, Workingmen's Democracy 4, 9 (1985); David MonTGomery, Citizen WORKER 13-51 (1993); RODGERS, supra note 6, passim; ALAN TRACHTENBERG, THE INCORPORATION OF AMERICA 74 (1982); SEAN WILENTZ, ChANTS DEMOCRATIC 92-97 (1984); Leon Fink, The New Labor History and the Powers of Historical Pessimism: Consensus, Hegemony, and the Case of the Knights of Labor, 75 J. AM. HIST. 115 (1988). On the origins of Americans' establishment of work as a critical constituent element of democratic citizenship, see GORDON S. WOOD, THE RADICALISM OF THE AMERICAN REVOLUTION 32-36, 276-86 (1992); and Gordon S. Wood, Ideology and the Origins of Liberal America, 44 WM. \& MARY Q. 628, 639-40 (1987).

17. See ERIC Foner, Free Soll, Free LABOR, Free MEN 16-17 (1970); WILENTZ, supra note 16, at 92-97; GoRdon S. WOOD, THE CREATION OF THE AMERICAN REPUBlic, 1776-1787, at 168-69 (1969); Robert J. Steinfeld, Property and Suffrage in the Early American Republic, 41 STAN. L. REV. 335,338 (1989); Sean Wilentz, Against Exceptionalism: Class Consciousness and the American Labor Movement, 1790-1920, 26 INT'L LAB. \& WORKING Class HiST. 1, 6-13 (1984).

18. See C.B. MacPherson, The Political Theory of Possessive Individualism 137-59 (1962).

19. See Steinfeld, supra note 17, at 348-49; see also William E. Forbath, The Ambiguities of Free Labor, 1985 WIS. L. REV. 767, 772-82.

20. In Sayre's view, "[t]he government . . . [was] the fruit of labor" and the laborer was the "lord of the realm." What Labor Is, 3 Locomotive FIREMEN's MonTHLY MAG. 272, 272 (1879). Sayre, the magazine's editor, believed that "[i]f the arm of labor is paralized, the nation perishes." Id. For Claxton, the "self-respect" inculcated by the diligence and creativity of work as a machinist or small-scale inventor, and the general mutual improvement of the laboring classes that accompanied such skilled work, would redound to the "benefit [of] the community at large." Timothy Claxton, MEMOIR OF a MECHANIC 91, 169 (Boston, George W. Light 1839). On workers' commitment to the dignity and value of work, see RODGERS, supra note 6 , at 174-77. 
moral culture" of a self-governing citizenry. ${ }^{21}$ Indeed, for Channing, it was the very "pains" that work could and did inflict that performed the morally constitutive work of labor. "[B]y its perils, which demand continuous vigilance," he argued, economic life developed critical moral and mental faculties. ${ }^{22}$

For those schooled in the ideology of republicanism, the expansion of wage earning as a permanent status for the working classes threatened to undermine the kind of economic autonomy necessary to sustain independent citizenship. ${ }^{23}$ But for others, skill in a trade and the capacity to exercise discretion over work could provide a modicum of economic independence for skilled workers even within the wage-labor employment relation. ${ }^{24}$ Skill in a trade could function as a kind of property, providing its owner with some of the same kinds of economic independence that had characterized the independent craftsmen of the late eighteenth and early nineteenth centuries. ${ }^{25}$ Thus, in addition to training workers for citizenship, skilled wage labor could sustain a modicum of the economic independence that had once been found in independent artisanal crafts. ${ }^{26}$

The work ethic, however, could also be put to uses that undermined worker independence. In the hands of employers, affirmations of the value of manual labor often served not so much to uphold the dignity of labor as to legitimate new forms of industrial exploitation. ${ }^{27}$ The moral value of work could become a moral imperative to labor, with less regard for the moral virtue that work could inculcate than for the maintenance of a bourgeois social order constructed at the expense of the laboring poor. ${ }^{28}$ Social Darwinist William

21. Horace Greeley, Recollections of a Busy Life 498 (New York, J.B. Ford \& Co. 1868); see also 5 William E. Channing, The Works of William E. Channing, D.D. 158 (Boston, Crosby, Nichols $\&$ Co. 12th ed. 1857). For Greeley, work and industry were necessary elements in the moral development of citizens because "[l]uxury enervate[d] the body and debase[d] the soul." GREELEY, supra, at 499.

22. 5 CHANNING, supra note 21 , at 158 .

23. Of course, as Robert Steinfeld observes, even ostensibly self-sufficient artisans were in many ways enmeshed in relations of interdependence. See Steinfeld, supra note 17, at 359-60.

24. See DAVID MONTGOMERY, WORKERS' CONTROL IN AMERICA 13-14 (1979) (describing skilled workers' capacity to exercise market power in the negotiation of work relations).

25. See John Rule, The Property of Skill in the Period of Manufacture, in THE HistoriCal MEANINGS OF WORK 99, 99-118 (Patrick Joyce ed., 1987).

26. Conceptions of citizenship that linked a modicum of independence in work-defined narrowly or broadly-to citizenship were often sharply exclusive. See, e.g., DAVID R. ROEDIGER, THE WAGES OF WhITENESS: RACE AND THE MAKING OF THE AMERICAN WORKING ClASS (1991) (describing the construction of a white working-class identity); Amy Dru Stanley, Conjugal Bonds and Wage Labor: Rights of Contract in the Age of Emancipation, 75 J. AM. HIST. 471 (1988) (describing the ways in which 19thcentury free labor ideology was predicated on male property rights in female labor). But see TERENCE VINCENT POWDERLY, THIRTY YEARS OF LABOR 1859-1889, at 631-32, 651-62 (Columbus, Ohio, Excelsior Publ'g House 1889) (describing the broadly inclusive nature of the Knights of Labor's late 19th-century producer ideology).

27. See Jonathan A. Glickstein, Concepts of Free Labor in ANTEbellum America 262 (1991) (describing the different ways in which the idea of the dignity of labor could be deployed); RODGERS, supra note 6, at 210-32 (describing the ideological uses to which the work ethic was put).

28. On the ways in which the moral value of work was transformed into a moral imperative to work by elites in the late 19th century, see Amy Dru Stanley, Beggars Can't Be Choosers: Compulsion and 
Graham Sumner, for example, argued that the correspondence "between work and reward" was the foundation of personal responsibility. ${ }^{29}$ For Sumner, that correspondence served to stigmatize "the woes of poverty... [and] the penalties of idleness." ${ }^{30}$ The role of "the faithful workman" in Sumner's view was to "subject himself to discipline." "I In this incarnation of the work ethic, bodily pain-even "the plucking out [of] an eye or cutting off [of] a limb," to use the words of New York charity organizer Josephine Shaw Lowell-served the critical role of disciplining the immoral poor who refused to work. ${ }^{32}$

\section{Control over the Processes of Production in the Nineteenth Century}

The plausibility of the nineteenth-century work ethic-in all of its forms-was sustained by an organization of work that, at least among the skilled white male industrial workers to whom the work ethic was usually attached, often left considerable room for worker discretion. To be sure, workers' informal control of work processes was often hotly contested by employers. By the middle of the nineteenth century, the material conditions that had sustained the artisanal republicanism of the early republic had been substantially undermined by growing inequality between master and journeyman and by the emergence of wage labor as the dominant economic relationship. ${ }^{33}$ Moreover, many employers sought to impose their own control over work through hierarchical shop-floor discipline of their workforces. Such employers posted workplace regulations, ${ }^{34}$ demanded that workers accustomed to preindustrial agricultural rhythms adapt themselves to new and rigid work schedules, ${ }^{35}$ and established a new class of foremen and room overseers to supervise the processes of production. ${ }^{36}$

Contract in Postbellum America, 78 J. AM. HIST. 1265 (1992), which describes an increase in vagrancy prosecutions and coercive enforcement of labor discipline among the laboring poor in the 1870s.

29. William Graham Sumner, The Shifting of Responsibility, in 2 ESSAYS OF William Graham SUMNER 260, 261 (Albert Galloway Keller \& Maurice R. Davie eds., 1934) (1887).

30. Id. at 262 .

31. Id. at 261 .

32. Josephine Shaw Lowell, Public Relief and Private Charity 94 (Arno Press \& The New York Times 1971) (1884). Josephine Shaw Lowell was not related to Chief Justice Shaw.

33. See DAVId MONTGOMERY, Beyond Equality, LABOR AND THE RADICAL REPUbliCANS 18621872 , at 30 (1967) (estimating that roughly two-thirds of those who worked outside the home were wage earners by 1870); RODGERS, supra note 6, at 36-37 \& $250 \mathrm{n} .12$ (same).

34. For examples of workplace regulations and employers' attempts to enforce them, see JONATHAN PRUDE, THE COMING OF INDUSTRIAL ORDER: TOWN AND FACTORY LIFE IN RURAL MASSACHUSETTS, 1810 1860, at 129-31 (1983); ANTHONY F.C. WALLACE, RoCKDALE: THE GROWTH OF AN AMERICAN VilLAGE IN THE EARLY INDUSTRIAL REVOLUTION 178-79 (1978); and DAVID A. ZONDERMAN, ASPIRATIONS AND ANXIETIES: NEW ENGLAND FACTORY WORKERS AND THE MECHANIZED FACTORY SYSTEM 1815-1850, at 144-62 (1992).

35. See Herbert G. Gutman, Work, Culture, And Society in InduStrializing America 3-78 (1977); $c f$. E.P. Thompson, Time, Work-Discipline, and Industrial Capitalism, 38 PAST \& PRESENT 56, 7995 (1967) (describing the collision of preindustrial work rhythms and industrial factory management in 18th- and early-19th-century England).

36. See PRUDE, supra note 34 , at $82-84$. Employer control was particularly effective in the textile 
Yet recent scholarship has revealed that a number of nineteenth-century firms and industries adopted management practices and strategies that relied on the preservation of a skilled workforce. ${ }^{37}$ Such firms did not engage in the harsh deskilling and hierarchical rulemaking that characterized industrial work in places such as the New England textile mills. At the Baldwin Locomotive Works in Philadelphia, for example, a producerist ethic linked employers and workers together as partners in the work of skilled production. ${ }^{38}$ Moreover, even as some employers sought to impose new forms of discipline in the industrial workplace, workers actively resisted their attempts and were often able to retain considerable discretion in the direction of their labor. ${ }^{39}$ Indeed, in many emerging forms of industrial work, workers were able to establish considerable amounts of discretion and control over their labor. Practices such as inside contracting permitted skilled workers to take charge of particular production projects. ${ }^{40}$ In iron rolling, for example, workers collectively contracted with their employer on only the total tonnage rate and controlled the division of labor and the allocation of pay themselves. ${ }^{41}$ For other skilled

factories of New England and Pennsylvania, which employed large numbers of unskilled workers, many of them women. See Thomas Dublin, Women at Work: THE Transformation of Work and COMMUNITY IN LOWELL, MASSACHUSETTS, 1826-1860, at 59-60 (1979); see also WALTER LICHT, INDUSTRIALIZING AMERICA: THE NINETEENTH CENTURY 29 (1995) (describing the centralization of production in New England industries in 1830s and 1840s); CYNTHIA J. SHELTON, THE MILLS OF Manayunk: Industrialization and Social Conflict in the PhILADELPHIA REGION, 1787-1837, at 6364, 73 (1986) (describing managerial rulemaking and the replacement of skilled, independent male workers with labor-saving machinery and female operatives in Pennsylvania textile firms in the 1820s); CHRISTINE STANSEll, CitY OF WOMEN: SEX AND ClASS IN NEW YORK, 1789-1860, at 121-23 (1986) (noting that in industries employing large numbers of women, work relations between male employers and female employees were often constructed along familial lines in accordance with views of the propriety of patriarchal control of the family). Moreover, new technologies such as the sewing machine transformed industries like shoemaking and garmentmaking and still further reduced workers' capacity to exercise skill and discretion over work processes. See MARY H. BLEWETT, MEN, WOMEN, AND WORK: ClASS, GENDER, AND Protest in the NeW ENGland Shoe INDUSTRY, 1780-1910, at 97 (1988); Alan DaWley, Class AND Community: The Industrial Revolution in LynN 76-78, 90-96 (1976); Jonathan Prude, Capitalism, Industrialization, and the Factory in Post-Revolutionary America, in WAGES OF INDEPENDENCE: CAPITAliSM IN THE EARly AMERICAN RePUblic 81, 92-93 (Paul A. Gilje ed., 1997) [hereinafter WaGES OF INDEPENDENCE].

37. See, e.g., John K. Brown, The Baldwin Locomotive Works 1831-1915, at 125, 130-32 (1995); Philip Scranton, Proprietary Capitalism: The Textile Manufacture at Philadelphia, $1800-1885$, at 52-53, 314-52 (1983).

38. See, e.g., BROWN, supra note 37 , at 95 (describing employer-employee relations and the culture of work at the Baldwin Locomotive Works in Philadelphia).

39. See, e.g., ZONDERMAN, supra note 34, at 56-61 (describing machinists' reactions to industrialization in the $1840 \mathrm{~s}$ and arguing that machinists developed a conception of themselves as "industrial artisan[s]"); Richard Stott, Artisans and Capitalist Development, in WAGES OF INDEPENDENCE, supra note 36 , at 101, 105-07 (describing the continuity of work practices in many trades into the late 19th century).

40. On inside contracting, see BROWN, supra note 37, at 115-19; DAN CLAWSON, BUREAUCRACY AND THE LABOR PROCESS: THE TRANSFORMATION OF U.S. INDUSTRY, 1860-1920, at 71-125 (1980); LiCHT, supra note 36, at 129-30; DAVID MONTGOMERY, THE FALL OF THE HOUSE OF LABOR: THE WORKPLACE, THE STATE, AND AMERICAN LABOR ACTIVISM, 1865-1925, at 9-19 (1987); John Buttrick, The Inside Contract System, 12 J. ECON. HIST. 205 (1952); and Ernest J. Englander, The Inside Contract System of Production and Organization: A Neglected Aspect of the History of the Firm, 28 LAB. HIST. 429 (1987).

41. See MONTGOMERY, supra note 40, at 9-19. 
craftsmen such as coal miners, steel workers, and machinists, specialized skills and knowledge made it possible to remain relatively self-directing in the details of industrial work processes. ${ }^{42}$ Even late into the nineteenth century, skilled workers were able to employ union work rules and cross-union sympathy strikes to maintain a modicum of collective self-direction in the processes of production. ${ }^{43}$

Railroads developed some of the earliest recognizably modern industrial management practices, including long codes of workplace regulations to govern workers' conduct in the workplace. ${ }^{44}$ Despite railroad company attempts to introduce new modes of managerial control, however, engineers, firemen, brakemen, and conductors maintained considerable informal control over the day-to-day conduct of their work by persistently ignoring or deliberately defying railroad company work rules in favor of customs and practices they had developed among themselves. ${ }^{45}$ Moreover, until late in the century, railroad managerial practices, such as the tradition of assigning work crews their own engines and the relatively clumsy and erratic use of suspensions as a mode of enforcing work rules, may have fostered a culture of worker control in ways wholly unintended by management. ${ }^{46}$

\section{The Common Law of Work Accidents and Workplace Control}

Courts played a central role in structuring the control of the emerging industrial workplace. Early- and mid-nineteenth-century American courts dismantled many of the disciplinary powers of eighteenth-century employers. ${ }^{47}$ Yet these same courts also helped to construct a new mode of

42. See DAVID BRody, Workers in INDUSTRIAL AMERICA 3-4 (1980) (discussing coal miners); JAMES Whiteside, Regulating Danger: The Struggle for Mine Safety in the Rocky Mountain Coal INDUSTRY 43-44 (1990) (same); MONTGOMERY, supra note 40, at 10-22 (discussing steel workers); DAVID MONTGOMERY, WORKERS' CONTROL IN AMERICA 11 (1979) (discussing worker control among "[i]ron molders, glass blowers, coopers, paper machine tenders, locomotive engineers, mule spinners, boiler makers, pipe fitters, typographers, jiggermen in potteries, coal miners, iron rollers, puddlers and heaters, the operators of McKay or Goodyear stitching machines in shoe factories, and, in many instances, journeymen machinists and fitters in metal works").

43. See MONTGOMERY, supra note 42 , at 10, 15-27.

44. See Alfred D. Chandler, JR., The Visible Hand: The Managerial Revolution in AMERICAN BUSINESS 81-144 (1977) (describing the development of new managerial technologies by railroad companies); WALTER LICHT, WORKING FOR THE RAILROAD 80-89 (1983) (describing railroad work rules); see also JAMES H. DUCKER, MEN OF THE STEEL RAILS 30-33 (1983) (same).

45. See LICHT, supra note 44, at 93-111. Railroad workers, managers complained, did not have "the right kind of sentiment." Id. at 97. They were continuously setting their own "rules for the regulation of their own conduct." Id.; $c f$. Murray v. South Carolina R.R., 26 S.C.L. (1 McMul.) 385, 386 (1841) (describing a worker plaintiff who selected on his own the engine and crew with which he would work).

46. In the 1890 s, railroad companies began to shift to a method of "pooling" engines such that work crews were no longer able to learn the quirks and characteristics of a single piece of machinery. See DUCKER, supra note 44 , at 117-18. In these same years, the railroads moved away from clumsy and arbitrary suspensions and firings and developed a complex scheme of merits and demerits that allowed them to exercise considerably more subtle forms of work rule enforcement. See id. at 38-39.

47. See Robert J. Steinfeld, The InVention of Free Labor 143-50, 152-53 (1991) (describing the demise of specific enforcement and criminal sanctions to enforce labor contracts and the rise of criminal 
employer control in the nineteenth-century workplace. Doctrines such as the "entire contract" rule, which denied workers' quantum meruit claims for back pay when they quit before the end of the term of an employment contract, ${ }^{48}$ and the enforcement of employer work rules and notice requirements as binding terms of the employment contract, even when the rules had been modified during the course of employment, systematically disadvantaged employees. ${ }^{49}$ In these respects, the nineteenth-century law of employment adopted a contractual approach to the employment relation that could serve to obscure and render indirect an employer's power to coerce his employees. ${ }^{50}$

The nineteenth-century law of workplace accidents captured the ambiguities of the legal construction of the industrial workplace. The common law rules could allow contract to become compulsion, thereby obscuring the exercise of employer power. Courts adjudicating work accident cases, for example, adopted employer-made work rules and employers' orders as setting the terms of the employment relationship and rewarded employee obedience to those rules and orders. Thus, the doctrine of employee work-rule violations held almost uniformly that an employee injured while violating an employer order or work rule was guilty of contributory negligence and thus unable to recover. ${ }^{51}$

cases brought against employers and supervisors for physically disciplining employees); see also TERESA ANNE MurPhy, TEN Hours' LabOR: Religion, Reform, \& GENDER IN EARly New ENGland 1-2 (1992) (describing the criminal sanctions levied against a New England mill foreman for whipping a female mill hand).

48. See, e.g., Stark v. Parker, 19 Mass. 267 (1824); see generally Wythe Holt, Recovery by the Worker Who Quits: A Comparison of the Mainstream, Legal Realist, and Critical Legal Studies Approaches to a Problem of Nineteenth Century Contract Law, 1986 WIS. L. REV. 677 (arguing that courts began to deny workers' quantum meruit claims in the first half of the 19th century); Peter Karsten, "Bottomed on Justice": A Reappraisal of Critical Legal Studies Scholarship Concerning Breaches of Labor Contracts by Quitting or Firing in Britain and the U.S., I630-1880, 34 AM. J. LEGAL HIST. 213 (1990) (arguing that the entire contract rule was not a new orthodoxy but rather marked a continuity with 18th-century law).

49. See TOMLinS, supra note 15, at 284-90 (describing courts' enforcement of employer work rules). Other examples include the doctrine of enticement, which punished unions and employers who encouraged employees to exit from existing employment relations, see, e.g., Walker v. Cronin, 107 Mass. 555 (1871) (deciding a civil action against a strike leader for interference with the employment relation between an employer and shoemakers who had not signed a contract and who were paid by the piece); Carew v. Rutherford, 106 Mass. 1 (1870) (upholding an employer suit against a labor union for enticing workers to strike); ORREN, supra note 15, at 105-08, 122-28 (describing the law of enticement); TOMLINS, supra note 15, at 280-84 (same), and the enforcement of broad criminal conspiracy and restraint-of-trade rules, see Victoria C. HATTAM, LABOR VISIONS AND STATE POWER 30-75 (1993); TOMLINS, supra note 15, at 107 219.

50. Cf. STEINFELD, supra note 47, at 157 (arguing that the "power that remained with the employers was no longer the legal power directly to coerce but the legal power indirectly to coerce by withholding from workers the means of subsistence").

51. See, e.g., Rome \& D.R.R. v. Chasteen, 7 So. 94, 97 (Ala. 1889) (rejecting a jury charge that would have allowed an employee to recover from a railroad company for injuries arising out of a violation of railroad company orders); O’Brien v. Staples Coal Co., 43 N.E. 181, 181 (Mass. 1896) (upholding a directed verdict against an employee injured while crossing over a hoisting apparatus in violation of employer orders). See generally 1 C.B. LABATT, COMMENTARIES ON THE LAW OF MASTER AND SERVANT $\$ \S 363-67$, at 941-67 (1904) (collecting cases). Failure to adopt the common law doctrine of employee work rule violations, argued supporters of the common law rules, would undermine employer control by allowing employees to recover regardless of their obedience to the employers' rules. See Little Miami R.R. v. Stevens, 20 Ohio 415, 428 (1851) (arguing that abandoning common law would mean that "no matter 
Moreover, in work accident cases courts put the nineteenth-century work ethic to dubious use by affirming the importance of worker control over their work and their working conditions in ways that placed the blame for accidents on the workers themselves-even in cases in which the injured employee could not have influenced or controlled the circumstances leading to the accident. By turning the work ethic into a moral imperative, the injured worker, like the unemployed worker, became morally suspect for failing to live up to his responsibility for the conditions of his work. ${ }^{52}$ In such cases, courts deflected the issue of employers' power over their employees by appealing to the work ethic and the notion that moral character inhered in the sound exercise of discretion in the workplace. ${ }^{53}$

Nonetheless, when courts asserted that employees "knew as much with respect to the safety of the [work]place" as their employers ${ }^{54}$ they appear to have been engaged in something other than willful hypocrisy. Nineteenthcentury work accident cases articulated a remarkably narrow conception of the possibilities for pervasive and far-reaching managerial control of the workplace. The courts accordingly denied claims when they arose out of "one

what rules the board of Directors establish for the safety of life and property, still the agent may or may not observe them as he pleases [without any impact on his chances of recovery]"). On this point in the English law of work accidents, see KostaL, supra note 7, at 265. See also Priestley v. Fowler, 150 Eng. Rep. 1030, 1033 (Ex. 1837) ("[T]o allow this sort of action to prevail would be an encouragement to the servant to omit that diligence and caution which he is in duty bound to exercise on the behalf of his master.").

52. See, e.g., Honner v. Illinois Cent. R.R., 15 Ill. 550, 552 (1854) (contending that the dangers of industrial work "depend[ed] very much upon the skill and care of the servants of the company"); see also Chicago \& Great E. Ry. v. Harney, 28 Ind. 28, 30 (1867) (claiming that an employee "has, commonly, better opportunities than the employer of learning the incompetency or carelessness of his fellow-servant"); Sullivan v. Mississippi \& Mo. R.R., 11 Iowa 421, 424 (1860) (arguing that employees could "better ... guard against such risks and accidents, than could the employer"); Parker v. Hannibal \& St. J.R.R., 19 S.W. 1119, 1127 (Mo. 1892) (Black, J., concurring) (concurring in the denial of a worker's claim on the ground that safety on the track depended "on the care and skill with which each shall perform his appropriate duty"); Ryan v. Cumberland Valley R.R., 23 Pa. 384, 385 (1854) (contending that employees "ought to know more" about their working conditions than their employers).

53. In Farwell, Shaw argued that the fellow servant doctrine rested on the "great principle of social duty" that required every man to be responsible to himself and others "in the management of his own affairs." Farwell v. Boston \& W.R.R., 45 Mass. (4 Met.) 49, 55-56 (1842). Such uses of the idea of personal responsibility-especially given that Farwell's injury was due to the negligence of a switchman whom Farwell had likely never met and over whom Farwell certainly had no control-functioned to obscure (1) that employees on the railroads were in fact engaged in wage labor for the benefit of the railroad company and its shareholders; and (2) that the legally constructed employment relation did not give employees the kind of power that they would have needed to exercise such responsibility over their working conditions. William Graham Sumner's views, expressed in an 1887 essay, performed precisely the same work. According to Sumner, the common law of work accidents properly described employees as "independent members of society, each pursuing happiness in his own way." SUMNER, supra note 29, at 263. The law, on this view, served the salutary function of promoting employee responsibility for working conditions. Yet just a paragraph later Sumner observed that because the worker (like the bondholder) held a "specific" or fixed interest in the firm and thus was "free from risk," he was properly "excluded from control" of the firm. Id. at 264. Sumner, then, affirmed the value of employee responsibility for the risks of work even as he precluded workers from exercising the kind of control that could have influenced working conditions.

54. Kimmer v. Weber, 45 N.E. 860,861 (N.Y. 1897). 
of the details of the business that is generally left to the workmen themselves." 55 A master, it was held, was not bound to "supervise and direct every detail of [his workers'] labor." ${ }^{, 56}$ Consequently, courts declined to extend an employer's duty of "personal supervision" "down in the chain of delegated appointments." ${ }^{57}$ Instead, they held that a railroad was not responsible for supervising the details of the work process $;{ }^{58}$ that an employer was not obliged to "oversee and supervise the execution detail of all mechanical work carried on under his employment"; $; 9$ and that an employer was "justified in leaving to [the employees] the exercise of their own discretion and judgment."

By contrast, the few judges who rejected the fellow servant rule and upheld employers' vicarious liability for the negligence of one employee that resulted in injury to another did so by appealing to the importance of effective managerial control over the workplace. The Wisconsin Supreme Court rejected the fellow servant doctrine by articulating a broad conception of employer control and arguing that such control over the conduct of employees implied an obligation to pay for injuries to one employee caused by another employee's negligence. ${ }^{61}$ In the Wisconsin court's view, the fellow servant rule "overlook[ed] the real influence which the liability to an action" would have on employers to exert control over the processes of production in order to reduce accident risks. ${ }^{62}$ Along slightly different lines, Justice Robert B. Warden of the Ohio Supreme Court claimed that the law ought to reward employee obedience by ensuring that obedient employees recovered ${ }^{63} \mathrm{He}$ argued against adoption of the fellow servant rule because an employee who "agree[d] to be faithful" ought to be able to recover from his employer for the negligence of a fellow employee. ${ }^{64}$ Warden even speculated that the employee "watchfulness" that the common law rules claimed to promote might be turned by employees against their superiors and would thus "be an end of all ... subordination" in the workplace. ${ }^{65}$

55. Id.

56. 2 LABATT, supra note $51, \S 586$, at 1719 n. 1 .

57. Michigan Cent. R.R. v. Dolan, 32 Mich. 510, 513 (1875).

58. See, e.g., Central R.R. v. Keegan, 160 U.S. 259, 267 (1895)

59. Hussey v. Coger, 20 N.E. 556, 559 (N.Y. 1889).

60. Besel v. New York C. \& H.R.R.R., 70 N.Y. 171, 176 (1877).

61. See Chamberlain v. Milwaukee \& Miss. R.R., 11 Wis. 238, 251-56 (1860). The Wisconsin court was the only state supreme court squarely to reject the fellow servant doctrine, but it soon overruled itself in Moseley v. Chamberlain, 18 Wis. 700 (1867).

62. Chamberlain v. Milwaukee \& Miss. R.R., 11 Wis. at 255.

63. See Cleveland, C. \& C.R.R. v. Keary, 3 Ohio St. 201, 227 (1854) (Warden, J., concurring).

64. Id.

65. Id. at 225. Justice Warden suggested that the fellow servant doctrine would nonetheless be appropriate for those employments "in which large and uncontrollable masses of men engage." Id. at 226. The extent to which employees' mutual watchfulness could subvert authority calls into question Tomlins's contention that the common law rules imposed an Orwellian "constant gaze of self-imposed or peerimposed discipline" on workers. TOMLINS, supra note 15, at 362. The interdependence of workers looks as much like mutual solidarity as Orwellian surveillance. 
Just as courts seeking to extend liability were required to invoke a broad conception of employer control of work processes, injured employees were required to appeal to a notion of broad employer responsibility for the workplace in order to frame claims of vicarious liability against employers. In the 1837 case of Barnes v. Boston \& Worcester Railroad ${ }^{66}$ for example, the Massachusetts Court of Common Pleas sustained the claim of an injured railroad employee similar to the claim brought several years later in Farwell.$^{67}$ According to Tomlins, the case represented the law's opportunity to recognize the "public interest in the conditions prevailing in industrial workplaces." ${ }^{68}$ Yet Barnes's claim appears to have advanced the idea that, like the master of a former age, the employer possessed a quasi-jurisdictional responsibility for the workplace. ${ }^{69}$ As historian Robert Wiebe has observed, the Barnes case adopted a language of deference. ${ }^{70}$ Counsel for Barnes denied any intention of attacking the "numerous excellent gentlemen" of the railroad company's management. ${ }^{71}$ Instead, he appealed to the notion that the railroad had been obliged to "provide Barnes with a safe means of transportation." 72 Yet in making that appeal, Barnes was required to frame his argument in a way that could legitimate the control of his employer. The critical point was that the railroad was responsible for Barnes's injury because its management

66. Barnes is not a reported case. We know of Barnes thanks to Tomlins's research efforts. See TOMLINS, supra note 15, at 301-03, 331-33, 341-47.

67. The court made a preliminary finding in favor of the employee, but while the railroad company's appeal was pending, the parties consented to submit the case to arbitration. The employee was awarded $\$ 3000$ in damages in the arbitration proceeding. See id. at $331-32,345$.

68. Id. at 346.

69. In the 18th century, employers' obligations for the upkeep of injured servants had been linked to hierarchical status relations that gave employers considerable disciplinary authority over the employees for whose health and upkeep they were responsible. On the colonial practice of enjoining from "putting out" sick or injured apprentices and indentured servants, see STEINFELD, supra note 47, at 25, 49, 59, 154-55. This legal obligation did not extend to wage laborers, who were not understood to be within the household jurisdiction of the master. See id. at 25 . Nonetheless, even as late as the Early Republic, the distinction between wage and domestic labor was blurred by a household model of economy in which residence and work were often overlapping categories and in which wages were often paid in the form of room and board. See Elizabeth Blackmar, MANHATTAN FOR RENT, 1785-1850, at 51-60 (1989) (describing the practice of "found labor" in artisanal shops). Even after the development of the fellow servant rule, slaves and seamen were exempted from the contractarian logic of the law of workplace accidents. See THOMAS D. MORRIS, SOUTHERN SLAVERY AND THE LAW, 1619-1860, at 147-58 (1996) (discussing the considerable scholarship on the application of work accident doctrines to slaves and arguing that southern law approached the fellow servant problem from the legal framework of the law of bailments, thus treating the slave as property within the control of the bailee); see also The City of Alexandria, 17 F. 390, 393-96 (S.D.N.Y. 1883) (holding that seamen are "entitled to be cured of all sickness or injuries occurring while in the ship's service" but noting that the "rule is limited to the cure of sickness or injuries, and does not include any compensation or allowance for the effects of the injury"). Like slaves, seamen were bound into their employment by employer disciplinary powers unknown to the free-labor employment relation. See Marcus Rediker, Between the Devil and the DeEP Blue SEA 186-98 (1987) (describing labor discipline on ships).

70. See Robert H. Wiebe, Self-Rule: A Cultural History of American Democracy 93 (1995).

71. TOMLINS, supra note 15, at 332 (quoting Abraham Moore, Barnes's counsel).

72. Id. 
had controlled the operations. ${ }^{73}$ Employees, then, were required by the structure of the law of work accidents to shape their claims in a way that affirmed employers' control over their own work. ${ }^{74}$

The rules of fellow servant, assumption of risk, and contributory negligence may even have encouraged the persistence of informal worker control within the wage labor employment relation by structuring the law to minimize employers' interests in exercising thorough control over production. To be sure, the common law rules could create positive incentives for employee obedience. But employees' first priority must surely have been to avoid accidents altogether rather than obey work rules in order to retain the ability to recover in case of accident. For employers, on the other hand, a legal regime that imposed liability for work accidents could have created incentives to increase the extent of their control over the workplace and over the day-today conduct of employees. The courts themselves appear to have believed that there was a correspondence between liability and control. As we have already seen, the Wisconsin Supreme Court's rejection of the common law rules rested in part on the claim that increased exposure to liability would induce employers to exert increased control over production. ${ }^{75}$ Moreover, in accident cases involving passengers rather than workers, the U.S. Supreme Court argued that it was necessary to preserve employers' vicarious liability for accidents arising out of employee work rule violations in order to ensure that employers exerted "the most stringent enforcement of discipline" ${ }^{\text {"76 }}$ over their employees.

73. In this respect, it is noteworthy that Barnes was a recently hired maintenance worker rather than an engineer, fireman, or conductor, the employees that constituted the elite of the railway workers. See id. at 301 .

74. The Barnes case was hardly an isolated example of plaintiffs' appealing to principles of managerial control. In Olson v. Clyde, 39 N.Y. 425, 428 (1884), an injured worker argued that his case did not fall within the fellow servant doctrine because, like seamen, he had been bound to obey the orders of superiors at the pain of punishment by law. Likewise, in Cleveland, Columbus \& Cincinnati Railroad v. Keary, 3 Ohio St. 201, 203 (1854), the plaintiff's position was that where the employer had placed "one person in his employ under the direction of another," and where the subordinate employee "was acting under his orders and control, at the time he received the injury," a plaintiff might recover despite the general validity of the fellow servant rule. It is precisely this way in which the law shapes an individual's claim so as to legitimate authority that some historians have identified as the source of law's hegemonic power. See, e.g., EUGENE GENOVESE, ROLL, JORDAN, ROLL 27 (1974) (arguing that the hegemonic function of the law resides in its power to frame the claims of the subordinated in terms set by those in authority (citing

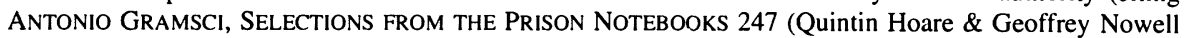
Smith eds. \& trans., International Publishers 1971) (1948))). The point here is that the common law of work accidents discouraged this kind of hegemonic formation by rejecting claims that tacitly appealed to and legitimated employer authority. Of course, as Genovese's interpretation of the law of slavery argues, the law's rejection of claims could serve to reproduce private forms of authority by leaving workers (or, in Genovese's account, slaves) with nowhere to turn except to the paternalism of the employer (or master). As almost all writers on the subject agree, however, employer benevolence in accident cases was spotty at best. See, e.g., LiCHT, supra note 44, at 201-11. Only in the last third of the 19th century did some firms begin to develop private accident compensation funds. See Robert Asher, The Limits of Big Business Paternalism: Relief for Injured Workers in the Years Before Workmen's Compensation, in DYING FOR WORK 19, 21-23 (David Rosner \& Gerald Markowitz eds., 1989).

75. See supra text accompanying notes 61-62.

76. Philadelphia \& R.R.R. v. Derby, 55 U.S. 468, 487 (1852). As Justice Grier explained, 
Common law rules that limited the scope of liability, on the other hand, structured the law so as to relieve employers of the imperative of such "stringent enforcement" and in the process may have fostered a zone of relative autonomy for workers out on the rails or on the shop floor.

\section{The Politics of Nineteenth-Century Work Accident Law}

Like the ideology of free labor generally, the common law of work accidents was constructed in contradistinction to the relations of dependence and obligation that characterized slavery and indentured servitude. ${ }^{77}$ This dynamic had a deeply ambiguous impact on free labor in the North. The dignity that nineteenth-century Americans attributed to free labor became one of the foundations of the producer ideology of workers who sought to defend the dignity of their work and to better their working conditions. Yet the construction of the free labor employment relationship against the backdrop of an unfree "other" was in some ways a selective response to labor coercion that had the effect of legitimating nonslave forms of labor exploitation. ${ }^{78}$

Noting the ambiguity of the free labor relation is not to say that the common law of work accidents did not in each case favor employers over injured workers. It did, of course. But at the same time, the common law of work accidents reproduced the full ambiguity of the work ethic that-for sometimes very different reasons-so preoccupied a wide range of nineteenthcentury Americans. The ideal of self-direction in work and responsibility for one's working life and conditions could, in the hands of the courts in work accident cases, become ways to promote worker behavior that internalized work discipline. Yet ideas about worker responsibility for working conditions also placed a loose set of bounds on ideas about employers' capacity to exert control over the details of production.

Significantly, the labor movement's advocacy of employers' liability reform developed remarkably late. It was not until the 1870 s and 1880 s that

Such a qualification of the maxim of respondeat superior would, in a measure, nullify it. A large proportion of the accidents on railroads are caused by the negligence of the servants or agents of the company. Nothing but the most stringent enforcement of discipline, and the most exact and perfect obedience to every rule and order emanating from a superior, can insure safety to life and property. ... . If such disobedience could be set up by a railroad company as a Id. defence, when charged with negligence ... discipline would be relaxed ....

77. In dissenting to the adoption of the fellow servant doctrine in South Carolina, Judge J.B. O'Neall of the South Carolina Supreme Court reasoned that slaves' owners could recover from hirers when their slaves had been injured while on hire and that there could be "no difference in the law . . . [between] the white man [and] the slave." Murray v. South Carolina R.R., 26 S.C.L. (1 McMul.) 385, 404 (1841). But, of course, in Northern free labor ideology that distinction made all the difference in the world. See, e.g., N.M. Thygeson, Why Are the Decisions Under the Fellow-Servant Doctrine So Vacillating and Contradictory?, 31 AM. L. REV. 93, 97-98 (1897) ("A servant is no longer a tool or instrument in the hands of a master ....").

78. See David Brion Davis, The Problem of Slavery in the Age of Revolution 1770-1823, at $346-85,489-501$ (1975). 
work accident law reform appeared along with maximum hours laws, land reform, and labor conspiracy reform as a central goal in labor's legislative agenda. ${ }^{79}$ As the labor movement's adoption of the issue of work accident law reform in the 1870s and 1880s suggests, however, the changing structure of work in the last quarter of the nineteenth century was sharply undermining the material basis of the ideological commitment to the dignity of labor.

\section{E. The Decline of Fellow Servant: Accommodating and Enforcing Managerial Control}

The cruel irony of the common law doctrines in work accident cases was that the ideal of self-directed work had already begun to lose its salience by the mid-nineteenth century. ${ }^{80}$ In the years after the Civil War, and especially after the recession of the early 1870 s, the development of new technologies of managerial control accelerated and spread to new industries. ${ }^{81}$ As a result, if the notion that workers ought to and did have some kind of meaningful control over the conditions of their work may have been accurate in some cases in the 1840 s and 1850 s, by the 1880 s and 1890 s that notion had diverged sharply from the sociological conditions of the workplace.

79. The labor movement's legislative demands in the $1840 \mathrm{~s}, 1850 \mathrm{~s}$, and 1860 s centered on land reform and maximum hours legislation. For labor's political demands in these years, see the documents collected in 8 A DOCUMENTARY HISTORY OF AMERICAN INDUSTRIAL SOCIETY (John R. Commons et al. eds., 1910) [hereinafter DOCUMENTARY HISTORY]. In New York, labor activists advocated such legislative changes as land reform, mechanics' lien laws, minimum wage legislation for public works, maximum hours legislation, and repeal of the law of labor conspiracy, but not employers' liability. See The Congress of Trades, N.Y. Herald, July 26, 1850, at 1; The New York City Industrial Congress, N.Y. DAILY TRIB., Sept. 25, 1850, at 8 . It was only at the third annual congress of the National Labor Union in 1868 that employers' liability reform became a part of labor's national political platform. See 9 DOCUMENTARY HISTORY, supra, at 22324. In New York, the labor movement began submitting petitions to the legislature for employers' liability reform in 1881. See Robert Asher, Failure and Fulfillment: Agitation for Employers' Liability Legislation and the Origins of Workmen's Compensation in New York State, 1876-1910, 24 LAB. HIST. 198, 203 (1983). Yet the lateness with which labor adopted the issue of employers' liability was hardly because work accidents themselves were infrequent. Although work accident statistics are difficult to determine for the mid-19th century, newspapers were filled with work accident reports. See, e.g., Accidents, N.Y. TIMES, Sept. 1, 1853, at 6 (reporting on a man whose foot was crushed in a shipyard accident); Accidents, N.Y. TIMES, Sept. 2, 1853, at 6 (listing five work accidents, including a railroad accident, a fall from a derrick in a coal yard, and a laborer crushed by a fall of sand while digging); Affairs at the Brooklyn Navy Yard-Fatal Accident, N.Y. TIMES, Aug. 5, 1854, at 5. The infrequency with which personal injury claims of any kind-including work accident cases-were brought to court in the mid-19th century may help to explain labor's relatively late embrace of employers' liability reform. See RANDOLPH E. BERGSTROM, COURTING DANGER 20-21 (1991) (documenting growth of personal injury cases in New York City from $0.3 \%$ of all cases in 1870 to $10 \%$ of all cases in 1910 and finding no work accident cases at all in 1870).

80. See generally DAWLEY, supra note 36 (describing the transformation of work in the Lynn, Massachusetts shoemaking industry); SUSAN E. HIRSCH, ROOTS OF THE AMERICAN WORKING CLASS (1978) (describing the degradation of work among New Jersey artisans); BRUCE LAURIE, WORKING PEOPLE OF PHILADELPHIA, 1800-1850 (1980) (describing the degradation of work among Philadelphia artisans); WILENTZ, supra note 16, at 107-42 (describing the degradation of work among New York City artisans).

81. See CHANDLER, supra note 44, at 272-81; CLAWSON, supra note 40, at 167-201; JOANNE YATES, CONTROl Through COMMUNiCATION: The Rise OF SYSTEM IN AMERICAN MANAGEMENT 2-4 (1989); see also MONTGOMERY, supra note 33, at 6-8 (arguing that the critical turning point in the reorganization of the firm was the recession of 1873). 
The law of work accidents was not, however, wholly blind to new technologies of managerial control in the workplace. Accommodating the extension of managerial control, the law of workplace accidents began to splinter in the last quarter of the nineteenth century under the weight of a growing body of exceptions to the common law rules. ${ }^{82}$ The exceptions and caveats that threw the law of workplace accidents into disorder attached to precisely those characteristics of the organization of the industrial workplace most difficult to reconcile with the ideal of self-directed work. Thus, courts developed exceptions to the fellow servant doctrine for cases in which the negligent employee was employed in a "different department" of a large corporate employer than the injured employee, ${ }^{83}$ and for cases in which the negligent employee was a "vice principal" of the employer. ${ }^{84}$

The creation of exceptions to the denial of vicarious liability in work accident cases evinced an expanded conception of the possibilities of managerial control. ${ }^{85}$ As Jonathan Simon has argued, liberalizing work accident doctrines not only responded to changing technologies of workplace control that rendered old ideas of worker discretion obsolete, but also pushed employers to make their control of the workplace more effective ${ }^{86}$ Courts rewarded the perfection of managerial discipline of work by leaving employers subject to liability for poor managerial supervision of incompetent employees ${ }^{87}$ or failure to enact and enforce an effective regime of workplace

82. See, e.g., Hough v. Railway Co., 100 U.S. 213, 216-17 (1879) (listing exceptions); see also Friedman \& Ladinsky, supra note 14, at 59-65 (describing the weakening of the common law rules); Comment, supra note 13, at 600-18 (discussing the development of exceptions to the common law rules). In 1912, New York insurance company lawyer Harry B. Bradbury called the soon-to-be-obsolete common law "a conglomerate mass of heterogenous hodge-podge of rules, doctrines and exceptions, which no one pretend[s] to understand." HARRY B. BRADBURY, BRADBURY's WORKMEN's COMPENSATION AND STATE INSURANCE LAW OF THE UNITED STATES at Xiii (1912).

83. See, e.g., Northern Pac. R.R. v. Hambly, 154 U.S. 349, 357 (1894) (holding that the fellow servant rule attached only where the injured employee could be said to have had "contact" with the fellow servant whose negligence caused the injury); Gillenwater v. Madison \& I.R.R., 5 Ind. 339, 345 (1854) (establishing the different department rule where the employee was not able to "participat[e] in the duties" that led to the accident); Card v. Eddy, 28 S.W. 979, 981 (Mo. 1894) (holding that the fellow servant rule applied only between workers who could reasonably be said to have been "co-operating" with one another in a common task).

84. See, e.g., Cleveland, C. \& C.R.R. v. Keary, 3 Ohio St. 201, 210 (1854).

85. Legislatures joined in the creation of exceptions to the fellow servant rule as well. By 1906, seven state legislatures had abolished the rule of fellow servant while 18 others had modified it insofar as it applied to railroad employment. Twenty state legislatures had modified the assumption-of-risk doctrine; several had even moved to a rule of contributory negligence for workplace accidents. See Melvin Urofsky, State Courts and Protective Legislation During the Progressive Era: A Reevaluation, 72 J. AM. HIST. 63, 84 (1985).

86. See Jonathan Simon, For the Government of Its Servants: Law and Disciplinary Power in the Work Place, 1870-1906, 13 STUD. L. POL. \& SOC'y 105 (1993).

87. See id. at 117-20 (citing Chicago \& A.R.R. v. Sullivan, 63 Ill. 293 (1872)). Beginning with Farwell v. Boston \& Worcester Rail Road, 45 Mass. (4 Met.) 49, 62 (1842), courts had suggested that employers could be held liable for negligence in hiring, but courts appear to have broadened the doctrine in the 1880 s and 1890s. See 1 LABATT, supra note $51, \$ \S 177-79$, at $390-96$. 
rules and regulations. ${ }^{88}$ As with employee claims earlier in the century, these doctrines required injured employees to frame their claims in terms that demanded not an end to managerial discipline, nor even less discipline, but rather better and more consistent discipline. ${ }^{89}$

\section{The Politics of WorkPlace CONTROL AND the Ambiguities OF WORKMEN'S COMPENSATION}

The movement to enact workmen's compensation legislation arose out of a law of employers' liability that had become "“choked and crippled with exceptions" ${ }^{\prime 90}$ and that workers, reformers, and employers alike had come to see as unworkable. Workmen's compensation reform, however, was more than an attempt to bring justice and rationality to the law of workplace accidents. The common law of workplace accidents had reflected and reproduced a nineteenth-century work ethic that (for all its capacity for manipulation in the service of industrial employers) had maintained a complex relationship to informal worker control over the processes of production. The development of broad doctrinal exceptions in the last decades of the nineteenth century, in turn, had begun to indicate the breadth of new conceptions of managerial responsibility for work. The shift to workmen's compensation, then, signaled a decisive shift toward new technologies of control in the workplace and toward new ideas about the moral value of work.

\section{A. Workmen's Compensation: Standardizing Costs or Legitimating Control?}

To contemporaries, perhaps the most extraordinary feature of workmen's compensation was the speed with which it completely revolutionized the law of workplace accidents. ${ }^{91}$ That speed can be attributed largely to the way in

88. See Simon, supra note 86, at 120-24 (citing Sheehan v. New York Cent. \& H.R.R.R., 91 N.Y. 332 (1883)). In addition, statutory and judicial reform of the law of work accidents continued to reward employee obedience of employer work rules. See William M. McKinney, Statutory Changes in the Doctrine of Co-Service in the United States, 6 LAW Q. REv. 189, 195 (1890) (noting that, even in jurisdictions in which the fellow servant doctrine had been amended, employees could only recover for injuries "received while rendering the service required by the particular employment or in obeying the order of a superior to which the employé is bound to conform").

89. See Simon, supra note 86 , at 125 . The function of work accident suits, then, was similar to that of workplace safety legislation enacted in the post-Civil War years. Even as such legislation decreased the toll of industrial injuries in industries such as coal mining, it ironically increased workers' subordination to regimes of managerial control in the workplace. See ANTHONY F.C. Wallace, St. ClaiR: A NinETEENTH-CENTURY COAL TOWN's EXPERIENCE WITH A DISASTER-PRONE INDUSTRY 296 (1987); see also LICHT, supra note 44, at 124 (arguing that railroad workers led a movement from below in the late 19th century in favor of the increased rationalization of managerial authority).

90. Roscoe Pound, The Formative ERa of American Law 135 n.59 (1938) (describing the condition of the law of liability without fault in the late 19th century (quoting SIR FREDERICK POLLOCK, The Law of Fraud, MisRepresentation and Mistake IN British INDia 53-54 (Calcutta, Thatcher, Spink 1894))).

91. See, e.g., John R. COMmons \& JoHn B. ANDREWs, PRINCIPLES OF LABOR LEGISLATION 397, $414-$ 15 (rev. ed. 1920) (describing the speedy adoption of workmen's compensation legislation and the "rapid[]" 
which workmen's compensation brought together the two dominant strains of progressive thought: social connectedness and social efficiency. ${ }^{92}$ Workmen's compensation thus found the support of a coalition that included members from across the entire spectrum of progressivism. Business leaders from both large corporations and small- to mid-size manufacturing companies supported compensation legislation..$^{93}$ So, too, did government labor officials, labor economists, muckraking journalists, and reform-minded lawyers. In their view, the dictates of justice and efficiency were fully aligned. As the National Civic Federation, a prominent gathering of elite business and labor leaders, announced, workmen's compensation would at once further "'principles of private right and distributive justice." ${ }^{\prime 4}$

Since the late 1960s, historians have explained progressive business elites' support of workmen's compensation by arguing that the critical moving force behind the enactment of workers' compensation was big business's need to standardize or even reduce the costs of industrial accidents. ${ }^{95}$ The evidence from New York, however, suggests that insurance companies expected employers' costs to be considerably higher under workmen's compensation than they had been under the common law regime. ${ }^{96}$ Moreover, it is not clear that standardization was a "need" of the turn-of-the-century corporate economy. Insurance already allowed businesses to standardize the cost of

spread of accident prevention measures by employers as a result). The movement to enact compensation laws promised, in the words of one insurance industry commentator in 1912, "to sweep like a prairie fire [across] this country from the Atlantic to the Pacific. No prophet is needed to foresee that practically every State in the Union will soon have thrown the inhuman and obsolete code of Employers' Liability laws and practices into the scrap-heap . . . ." EDWARD BUNNELl PHELPS, WORKMEN's COMPENSATION 1 (1912).

92. For the idea that progressivism was characterized by the interwoven and sometimes competing strands of social connectedness and social efficiency, see Daniel T. Rodgers, In Search of Progressivism, 10 REVS. AM. HIST. 113 (1982). Rodgers suggests that antimonopoly should be understood as a third strand of progressivism, but that strand played little role in the story told here.

93. Indeed, the large corporations and elite labor leaders of the National Civic Federation, and the smaller manufacturing concerns of the National Association of Manufacturers-organizations that generally found themselves bitterly opposed to one another on issues relating to labor-both supported compensation legislation. See Ferd. C. Schwedtman, Relief Tendencies in the United States, AM. INDUSTRIES, Aug. 1911, at 19, 19 (writing as the head of the National Association of Manufacturers' Industrial Accident Indemnity Committee in the Association's trade publication that "[e]very student of the history of relief schemes for work accidents in foreign countries knows that compulsory action through state or federal laws is necessary to make satisfactory progress"); Accident Compensation, N.Y. TIMES, Aug. 7, 1911, at 11 (reporting the Civic Federation's advocacy of workmen's compensation).

94. Accident Compensation, supra note 93 (quoting a National Civic Federation committee report).

95. See LuBOVE, supra note 5, at 49; Weinstein, supra note 5.

96. See Aetna LifE InS. Co., New YoRK Employers' Liability and COMPENSATION Laws 10 (1910) (announcing a 50\% rate increase in response to New York's compensation legislation); PROCEEDINGS OF THE CONFERENCE OF COMMISSIONS ON COMPENSATION FOR INDUSTRIAL ACCIDENTS 7 (1910) [hereinafter CONFERENCE OF COMMISSIONS] (noting that insurance rates had risen under the compensation act as "we all knew would happen"); Frank E. Law, Letter to the Editor, N.Y. TimES, Aug. 30, 1910, at 6 (reporting that insurance companies were predicting higher rates); Thinks Employers Evade Liability Law, N.Y. TIMES, Oct. 12, 1910, at 10 (reporting that an insurance association had recorded a $20 \%$ increase in rates after enactment of the New York State compensation legislation); see also MARK ALDRICH, SAFETY FIRST: TECHNOLOGY, LABOR, AND BUSINESS IN THE BUILDING OF AMERICAN WORK SAFETY, 1870-1939, at 96-97, 344 n.49 (1997) (arguing that workmen's compensation did in fact have the effect of raising the cost of work accidents to employers). 
accidents absent reform. And as Edward Purcell has documented, many businesses actively exploited the uncertain outcome of particular lawsuits in order to maximize their leverage over individual claimants. ${ }^{97}$

The progressives' own explanations for the need to transform the law of industrial accidents lay slightly closer to the heart of the matter. In their view, the common law of work accidents had been created for "domestic or simple agricultural" occupations. ${ }^{98}$ In an "era of specialized labor, [and] of extreme complex machinery," ho however, an increased accident toll was now inevitable. ${ }^{100}$ What was needed, then, was a "reasonable body of new rules fitting the circumstances of modern industry."

There was a good deal of truth in the progressives' own account of the need for work accident law reform. As the recent work of economic historian Mark Aldrich has established, the late nineteenth century witnessed horrific growth in the absolute number and the rate of work injuries and fatalities. ${ }^{102}$ Nonetheless, like the so-called "needs" of nineteenth-century capitalism, neither the increase in accident rates nor a new conception of the inevitability of accidents are sufficient to account for the outpouring of support for workmen's compensation reform. Chief Justice Shaw, after all, had relied on the ordinary occurrence of accidents in the course of employment to conclude that employees could reasonably foresee the risk of accidents. ${ }^{103}$ And while progressives argued that the wage bargain did not in fact incorporate the risk of accidents, ${ }^{104}$ workmen's compensation statutes did not necessarily or

97. See Edward A. Purcell, Jr., Litigation and Inequality: Federal Diversity Jurisdiction IN INDUSTRIAL AMERICA, 1870-1958, at 63-64 (1992); see also Gordon, supra note 14, at 78-79 (critiquing arguments from corporate "needs" for cost standardization). Individual claimants were likely to be more averse to the risk of losing than corporate defendants because loss for the former, unlike the latter, often meant material destitution.

98. Will Irwin, The Awakening of the American Business Man, 82 CENTURY MAG. 118, 119 (1911); see also CRYSTAL EASTMAN, WORK-ACCIDENTS AND THE LAW 188 (1910) (advocating a departure from "ancient legal precedents"); REPORT TO THE LEGISLATURE OF THE STATE OF NEW YORK BY THE COMMISSION APPOINTED UNDER CHAPTER 518 OF THE LAWS OF 1909 TO INQUIRE INTO THE QUESTION OF EMPLOYERS' LIABILITY AND OTHER MATTERS 13 (1910) [hereinafter WAINWRIGHT COMMISSION REPORT] (arguing that the common law rules had become inappropriate for the "hazardous trades" of the early 20 th century).

99. Irwin, supra note 98 , at 119.

100. See WAINWRIGHT COMMISSION REPORT, supra note 98 , at 5.

101. National Indus. CONFERENCE Bd., WORKMEN's COMPENSATION ACTS IN THE UNited STATES: THE Legal PHASE 22 (1917).

102. See ALDRICH, supra note 96, at 79-91. Aldrich attributes the increase in work accidents to sectoral shifts in the economy from agriculture to industrial manufacturing, the mechanization of manufacturing, employer demands for increased production, the low cost of work accidents under the common law regime, and the persistence of work practices among many working men that sometimes sacrificed safety for a "manly" fearlessness. See id. Despite the general increase in work accident rates, the increases were uneven across different industries. On the railroads, for example, the introduction of automatic couplers after 1893 decreased accident rates in the coupling process. See id. at 25-39, 291 tbl.AI.5. In the coal mines, on the other hand, work accidents increased dramatically in the $1890 \mathrm{~s}$ and in the first decade of the 20th century. See id. at 42.

103. See Farwell v. Boston \& W.R.R., 45 Mass. (4 Met.) 49, 59 (1842).

104. See WAINWRIGHT COMmISSION REPORT, supra note 98 , at 7 (arguing that the "laissez-faire" tenet that the market would adjust wages upward in dangerous industries to reflect the risk of injury simply "does 
inevitably follow from that belief. Other reform steps such as minimum wage legislation or liberalization of the law of labor actions might have addressed the issue of new industrial conditions by raising wages (or allowing workers to raise them) in order to incorporate the risk of accidents into the wage bargain, or by giving workers the power to demand safety measures.

The moving force behind workmen's compensation legislation, then, was neither the "need" to standardize costs, nor the inevitability of accidents under modern industrial conditions. Rather, the critical factor was a revolutionary new aspiration for managerial control in the workplace to generate social efficiencies. For in addition to noting the inevitability of work accidents, progressives had begun to focus on new managerial technologies that might lower the toll of industrial injuries to its irreducible minimum.

\section{B. Scientific Management and Workmen's Compensation}

Despite the development of new methods of managerial control in the decades after the Civil War, the American industrial workplace continued to be characterized by antiquated theories of management into the first decade of the twentieth century. In the same years that the workmen's compensation movement was accelerating, however, progressive efficiency enthusiasts were remaking the sociology of the employment relation around Frederick Winslow Taylor's concept of scientific management.

Nineteenth-century approaches to management came under sharp criticism from Taylor. ${ }^{105}$ In Taylor's view, conventional managerial practices required that "each workman shall be left with the final responsibility for doing his job practically as he thinks best, with comparatively little help and advice from the management." ${ }^{106}$ As a result, instead of a standard practice for a given step in the production process, there were "fifty or a hundred different ways of doing each element of the work," ways that had "been handed down from man to man by word of mouth." 107 "[T] [any one worker] should hit upon the one best method of doing each piece of work out of the hundreds of possible methods which lay before him." 108

not work out"). Shaw, it should be noted, had not purported to describe reality so much as state a normative principle of contract law: the "legal presumption" that the wage bargain reflected the risk of accidents. Farwell, 45 Mass. (4 Met.) at 57.

105. For accounts of Taylor and scientific management, see SAMUEL HABER, EFFICIENCY AND UPLIFT: SCIENTIFIC MANAGEMENT IN THE PROGRESSIVE ERA, 1890 -1920 (1964); RobERT KANIGEL, ThE ONE BEST WAY: FREDERICK WINSLOW TAYLOR AND THE ENIGMA OF EFFICIENCY (1997); MONTGOMERY, supra note 40, at 214-56; DANIEl Nelson, MaNAGERS AND WORKERS 55-78 (1975); and Charles P. WREgE \& RONALD G. GREENWOOD, FREDERICK W. TAYLOR 97-125 (1991).

106. Frederick Winslow TAylor, The PrinCiPles of SCIENTIFIC Management 25 (W.W. Norton \& Co. 1967) (1911).

107. Id. at 31-32

108. Id. at 112. Thus, Taylor objected to the then-state-of-the-art managerial theory of creating a system of incentives in order to obtain the initiative of workers-what he called the "initiative and incentive" method of management-on the ground that merely giving workers the right incentives would 
Scientific reorganization of the processes of work, on the other hand, allowed management to "substitut[e] . . . science for the individual judgment of the workman." ${ }^{109}$ In light of the presumptive incapacity of the worker to comprehend adequately the processes of production, ${ }^{110}$ Taylor and the management specialists he inspired set out to eliminate the discretion of the individual worker." ${ }^{11}$ Scientific management's first principle was "the deliberate gathering in on the part of those on the management's side of all of the great mass of traditional knowledge, which in the past has been in the heads of the workmen, and in the physical skill and knack of the workmen." 12 Hence, Taylor developed a series of new managerial techniques, including standardized and minutely controlled processes of production and maintenance, and stopwatch time-study, to replace workers' informal know-how with ostensibly scientific rationality. ${ }^{113}$

Taylor's pretensions to scientific standards of management were in fact absurd, ${ }^{114}$ and the dream of completely removing discretionary power from the ranks of workers was one that could never completely be instituted. ${ }^{115}$ Yet the theory of scientific management came to enjoy widespread popularity. Even when specific programs were not put into action, scientific management captured the aspirations of management to exercise an extraordinary new disciplinary power in the workplace, and its widespread popularity among progressives signaled an acceptance of the idea that the workplace ought to be reorganized around efficient control of work processes by management. ${ }^{116}$

not guarantee that they would hit upon the most efficient means of doing the job. See id. at 34-36.

109. Id. at 114 .

110. Testifying before a congressional committee in 1912, Taylor claimed that "in practically all of the mechanic arts the science which underlies each workman's act is so great and amounts to so much that the workman who is best suited to actually doing the work is incapable, either through lack of education or through insufficient mental capacity, of understanding this science." Id. at 89.

111. The science of the expert was set squarely in opposition to the informal worker discretion in work processes that had characterized much 19th-century production. See id. at 63 (recognizing that the establishment of "new working habits ... [that were] in accordance with scientific laws ... [was] directly antagonistic to the old idea that each workman can best regulate his own way of doing the work"). On workers' bitter opposition to Taylorism, see MONTGOMERY, supra note 40, at 247-49.

112. FREDERICK WINSLOW TAYLOR, Taylor's Testimony Before the Special House Committee, in SCIENTIFIC MANAGEMENT 40 (1947).

113. See NELSON, supra note 105 , at 56.

114. As Robert Kanigel has shown in his recent biography of Taylor, the means by which Taylor and his disciples "scientifically" determined the best way to accomplish a particular task were themselves shot through with arbitrary value judgments. See KANIGEL, supra note 105, at 511-14 (describing the vulnerability of time-study to "trickery, self-delusion, error, and guess").

115. See GRAMSCl, supra note 74 , at 301-10 (observing that discretion is never completely removed from work processes).

116. Some recent scholarship has questioned the extent of Taylor's impact on modern industrial practices in terms of instituting particular managerial practices. See, e.g., Walter Licht, Studying Work: Personnel Policies in Philadelphia Firms, 1850-1950, in MASTERS TO MANAGERS 43, 72 (Sanford M. Jacoby ed., 1991); Daniel Nelson, Scientific Management and the Workplace, 1920-1935, in MASTERS TO MANAGERS, supra, at 74, 88-89. As Nelson observes, however, "There is little doubt that Taylorism in the most general sense, as a conception of management that transcended narrow functional activities, won wide acceptance." Nelson, supra, at 76. 
Workplace accident law reform and scientific management shared a common commitment to systematizing and rationalizing the governance of work. Both movements spoke the language of efficiency, ${ }^{117}$ and both movements sought to realize social gains (social productivity for Taylor and accident prevention for workmen's compensation advocates) by placing control in the hands of management. Indeed, by increasing employers' work accident costs, workmen's compensation accelerated the process by which management took increased control over the details of production. In the name of "safety first," American managers responded to workmen's compensation by developing detailed rules and regulations for particular work processes, dictating that workers wear certain kinds of clothing and protective gear, and generally undermining workers' control over their work lives. ${ }^{118}$

Moreover, both workmen's compensation and scientific management had abandoned the nineteenth-century linkage between work and the moral virtue necessary to sustain democratic citizenship. In the place of self-directed worker citizens, Taylorism posited a social order run and protected by experts who could distribute social costs in keeping with social benefits. Likewise, supporters of workmen's compensation argued that efficiency required that the system of accident compensation be rationalized and placed in the hands of rational administrative bodies precisely because production was and should be squarely within the control of management. What was needed, wrote one commentator, was a "scientific system of working-men's compensation." 119 "As the apostles of scientific management have shown us," he argued, "we Americans have wasted foolishly in the individual processes of our industry." ${ }^{120}$ In the view of progressive supporters of social insurance, it followed from the employer's control over the factors of production-employee and machine alike-that the employer was responsible for injuries that might occur to labor. "The wage-worker," wrote social insurance expert Charles Richmond Henderson, "has special claims upon collective consideration because he no longer has any ownership in the materials and instruments of production, nor any voice in management of the process nor control of the conditions under which his mind and body may suffer." 221 In Henderson's view, the economic condition of the modern wage worker, who was under the control of the "manager of business,",122 mandated provision of relief in instances of industrial suffering and distress.

Following Frederick Winslow Taylor, supporters of workmen's compensation placed control and responsibility directly in the hands of

117. See William Graebner, Coal-Mining Safety in the Progressive Period 159-60 (1976).

118. See ALDRICH, supra note 96, at 123-43.

119. Irwin, supra note 98 , at 118 (emphasis added).

120. $I d$.

121. Charles Richmond Henderson, Industrial Insurance in the United States 44 (1909).

122. Id. at 49 . 
management. John White of the New York Edison Company stated bluntly, "We feel that such expense [for employee injuries] should in the first instance be borne solely by the employer as one of the items in his manufacturing costs." ${ }^{23}$ Along the same lines, prominent Baltimore attorney J. Walter Lord argued that responsibility, not fault, was the true principle that ought to guide the law of workplace accidents. "The rule of personal liability," he declared, "rests not upon a notion of actual fault on the part of the individual charged with liability, but upon the reasonable imputation of fault arising out of his responsible connection with the instrumentality through which the injury was caused." 124

Workmen's compensation thus reaffirmed (and was itself reaffirmed by) the extension of managerial control represented by scientific management. Indeed, workmen's compensation also gave rise to a sophisticated new economic theory of work accident law that served to legitimate new aspirations for pervasive managerial control. On this view, employers and managers rather than workers were the parties with the expertise and the power to bring discipline to the workplace and reduce the accident toll by rationalizing the processes of production. ${ }^{125}$ As Progressive social insurance expert E.H. Downey argued, management control combined with managerial internalization of the costs of production would produce the socially optimal level of accident prevention and social goods production. ${ }^{126}$ The cost of accidents properly lay with the employer, on this reasoning, because control over work and the capacity to minimize the cost of accidents properly lay with the employer.

\section{Workmen's Compensation and the New Ideology of Work}

By raising the price of work accidents, the workmen's compensation statutes pushed management to develop new modes of control over work. ${ }^{127}$ The increased managerial adoption of responsibility for safety in the workplace in the years after the enactment of workmen's compensation had the important

123. WAINWRIGHT COMMISSION REPORT, supra note 98, at 130.

124. J. WALTER LORD, EMPLOYERS' LIABILITY AND WORKMEN'S COMPENSATION LAWS 13 (1912).

125. As William Graebner has observed, "The widespread use of the word discipline to describe a solution to the problem of mine accidents is perhaps the best indication that mine accidents and fatalities were believed to be caused by an absence of such discipline, by the absence of order and control." GRAEBNER, supra note 117 , at 162. Indeed, the same years that witnessed reform in work accident law saw the emergence of increased concern among public health professionals for the problem of industrial hygiene, a development that "emerged at once as a new branch of medicine and public health and, at least potentially, as a new extension of the managerial hand." CHRISTOPHER C. SELLERS, HAZARDS OF THE JOB: From Industrial Disease to Environmental Health SCIENCE 8 (1997). On the new managerial powers effected through industrial hygiene and their relationship to workmen's compensation laws, see $i d$. at $110-23$.

126. See E.H. DOWNEY, WorkmEN's COMPENSATION 9, 15 (1924) (advocating that employers be required to internalize the costs of work accidents in order to minimize the social cost of such accidents).

127. See ALDRICH, supra note 96, at 104 (arguing that workmen's compensation accelerated the fledgling safety movement in American industry by increasing the costs of accidents to employers). 
effect of reducing accident rates in American workplaces. ${ }^{128}$ But it also entailed compromising the kinds of informal worker practices and discretionary authority that had undergirded the idea of work's intrinsic value. ${ }^{129}$

The deep ambiguity of workmen's compensation, then, was that even as it reduced accident rates and sought to relieve injured workers from the harsh conditions they faced under the existing common law rules, it accommodated the law to the removal of workers' participation in the control of their working lives without conceiving of new ways to institutionalize worker selfgovernance. Workmen's compensation did not, of course, cause the erosion of worker discretion over the processes of production. Many reformers sought not so much to legitimate the existing conditions of industry as to describe them and construct some sort of pragmatic solution for the problem of industrial accidents. Crystal Eastman, for example, in her year-long study of the working conditions of Pittsburgh, sought to "work out a law of employers' liability which will approximate justice in the existing industrial world." 130 Because, as Eastman argued, only about one-third of industrial accidents could be traced to worker negligence, ${ }^{131}$ requiring employers to bear at minimum a significant share of the costs of industrial accidents could lead to a significant reduction in the annual toll of work injuries. ${ }^{132}$

Yet disentangling description from legitimation was a difficult task. If under modern work processes management was thought to be best able to prevent the majority of work accidents, disciplining management to require it to reduce work injuries could, ironically enough, work to ratify such work processes, and even to accelerate their establishment in laggard industries. ${ }^{133}$

128. See id. at 104, 284-314 (documenting declining accident rates and increased managerial concern for safety in the workplace in the post-workmen's compensation years); see also COMMONS \& ANDREWS, supra note 91, at 414 (arguing that increased safety provisions by management were traceable to the enactment of workmen's compensation statutes).

129. See ALDRICH, supra note 96, at 7 (arguing that the "safety first" movement required workers to trade away informal discretionary control in the workplace for increased safety); see also Kurt Wetzel, Railroad Management's Response to Operating Employee Accidents, I890-1913, 23 LAB. HIST. 351, 367-68 (1980) (arguing that the safety movement on the railroads was linked to scientific management's attempts to perfect managerial control over work).

130. EASTMAN, supra note 98 , at $188-89$ (emphasis added).

131. See id. at 95 (arguing that only $32 \%$ of work accident fatalities were attributable to worker negligence).

132. The existing law, in Eastman's view, failed to distribute the cost of accidents "so as to furnish the strongest inducement for the prevention of accidents." Id. at 165.

133. Pushing management to take preventive steps was a dominant theme in workmen's compensation reform arguments. According to the Wainwright Commission, employers gave too little attention to accident prevention "because the payment for the damages of accident bears very little direct relation under the present system of liability, to the number of accidents." WAINWRIGHT COMMISSION REPORT, supra note 98, at 7. Workmen's compensation, the Commission argued, "will have a real effect in making [the employer] put his mind constantly to the question of preventing accidents" because it would "make the employer pay something for every accident." Id.; see also John M. Gitterman, The Cruelties of Our Courts, 35 MCCLURE'S MAG. 151, 162 (1910) (arguing that “[t]he law ... simply encourages [employers'] negligence and increases the number of mishaps"). Within several years of the enactment of workmen's compensation legislation, labor economists believed that the transformation of work accident law had caused employers to make new efforts to prevent work accidents. See, e.g., CoMmONS \& ANDREWS, supra 
Ultimately, if only through force of repetition, the rhetorical moves proponents made in supporting workmen's compensation, along with the social efficiency logic of social insurance theorists such as Downey, helped to construct a new theory of work. This new discourse of work abandoned the principles of dignity in and discretion over the conduct of the work process that had characterized the nineteenth-century work ethic. Instead, it advanced a conception of work that envisioned workers as mechanistic automatons, that emphasized the hierarchical nature of the employment relationship, and that both reflected and gave shape to a transformation of the social meaning of work itself.

\section{Workers and Machines: The Problem of Commodification}

Just underneath the nineteenth-century ideal of the worker as self-directed and independent had been a haunting fear that modern industry might be reducing workers to the condition of mere machines. ${ }^{134}$ Progressives, however, did not resist the analogy of worker to machine so much as they embraced it as proof of the employer's responsibility to pay for industrial injuries to their workers. "[J]ust as employers now fix their selling price with reference to the cost of replacing and repairing machinery," argued the New York State commission appointed to investigate employers' liability, "so we would have them make an element of the price of the product the cost of relieving the injured workers of hazardous industry." 135 When "accidents befall machines," complained the editors of the Outlook, "the industry pays." 136 Why, then, when "those accidents befall men" did they "become a personal matter"? "137 What was needed, the editors noted, was a legal regime in which "the cost of the injury to men is put on the same basis as the cost of injury to machinery." 138 In progressives' analogies, the industrial workforce regressed into the machinery around them, as if there were no middle ground between autonomous agent and automaton. ${ }^{139}$

note 91 , at 414 .

134. By the 1890 s, the image of man as machine was able to spark real controversy, as when a New York audience reacted in a storm of protest to one speaker's suggestion that strikes were the justified reaction of workers to the "mechanicalization" of the workingman. See RODGERS, supra note 6, at 65-93; see also TRACHTENBERG, supra note 16, at 38-69. For workers' complicated and oft-contradictory responses to the introduction of mechanicalized production processes into the workplace in the early- and mid-19th century, see ZONDERMAN, supra note 34, at 21-62.

135. WAINWRIGHT COMMISSION REPORT, supra note 98 , at 7.

136. Workmen's Compensation: A New Bill, 1913 OuTLOoK 571, 571.

137. Id.

138. Weakening a Workmen's Compensation Law, 1915 OUTLOOK 748, 748.

139. See Edward A. Moseley, The Penalty of Progress, 64 InDEPENDENT 1340, $1342-43$ (1908) (arguing that because both workers and machines are "wasted" and "subjected to wear and tear," employers should bear the costs of accidents to both workers and machines); Sandy Hook's Guns Roar for Governors, N.Y. TIMES, Sept. 14, 1911, at 1 ("If the railroad has to pay for the engine that goes into a ditch, it ought to pay for the engineer who is killed." (quoting Governor Stubbs of Kansas)); S.H. Wolfe, Human Wear and Tear, 27 EVERYBODY's MAG. 758, 758-59 (1912) (arguing that human wear and tear, rather than its 
The problem of mechanicalization was exacerbated by the tendency of workmen's compensation reformers to equate workers' bodies with money payments. Holmes had observed in 1897 that the use of money awards to pay for bodily harm raised the specter of pricing human bodies. ${ }^{140}$ Recognizing this, reformers tried hard to make arguments that focused on the material needs of injured workers and their families rather than their rights to compensation. ${ }^{141}$ Crystal Eastman, for example, sought to argue that the existing system of employers' liability commodified the body just as much as any workmen's compensation scheme might. Illustrating her point with a photographic plate of Belgian sculptor Constantin Meunier's Puddler adorned with bold red arrows indicating the price tag that employers had attached to the eyes, arms, legs, and fingers of the Pittsburgh steel workers, Eastman made abundantly clear the commodifying impact of the common law; ${ }^{142}$ in her view, the only difference between workmen's compensation and the common law of work accidents was that the common law established shockingly stingy prices. ${ }^{143}$

Eastman's strategy, however, may only have heightened anxieties over the implications of paying for bodily damage. Reviewing her book in the Yale Review, Connecticut manufacturer Howell Cheney argued that Eastman's proposal for compensation paid through the government was based on a "mistaken" theory that some "amount of money can rightly compensate for the life of a husband, son, or brother." 144 Nagging concerns over commodification would only increase when, beginning with New Jersey in 1911, states began to move away from tying compensation to lost wages in favor of set levels of compensation for the loss of particular body parts. ${ }^{145}$

mechanical analogue, was the problem facing the nation's economy). Indeed, at times the picture of man-asmachine threatened to reduce the worker still further: In contrast to the machine, which was amenable to split-second timing and the demands of mass production, all too often the worker broke down on the job. See, e.g., DownEY, supra note 126, at 7; Daniel Cease, Employers' Liability, 1 AM. LAB. LEGIS. REv. 40, 45 (1910).

140. See O.W. Holmes, The Path of the Law, 10 HARv. L. REv. 457, 467 (1897) ("It is conceivable that some day in certain cases we may find ourselves imitating, on a higher plane, the tariff for life and limb which we see in the Leges Barbarorum."). Others expressed similar concerns. See, e.g., The Value of a Man, 64 INDEPENDENT 991, 991 (1908) ("Irrespective and above and beyond what may perhaps be called the machine value of a man, there is the man's value as a wealth producer that is not unlike the value an heirloom has beyond its intrinsic value."); Man's Value at 20 and 50, N.Y. TIMES, Nov. 7, 1911, at 7 (noting suspiciously that workmen's compensation reformers had "scientific[ally]" determined the value of a man's life at ages 20 and 50). On the persistence of such anxieties today, see MARGARET JANE RADIN, CONTESTED COMMODITIES 184-205 (1996).

141. See, e.g., William Hard, The Law of the Killed and Wounded, 19 EvERYBODY'S MAG. 361, 361 (1908).

142. See EASTMAN, supra note 98 , at $126-27$.

143. See id. (describing the inadequate compensation received by workers under the common law regime). On this same point, see Buying a Man's Arm, by the Corporation Lawyer Who Made the Purchase, 68 AM. MAG. 260, 260-61 (1909).

144. Howell Cheney, Work, Accidents, and the Law, 19 YALE Rev. 255, 260 (1910) (book review). Human beings and money, Cheney argued, were not "commercial equivalents." Id.

145. See 3 COMmONS ET AL., supra note 4, at 603-04. States had found it disconcerting that a worker who lost a body part but was able to continue working without interruption would recover nothing. See, 
Elaborate schedules resulted, assigning different dollar values to different parts of the human body. Both a workman's feet, reported the New York State Department of Labor in 1916, were worth $\$ 6083.61$; loss of both eyes entitled a worker to $\$ 5842.08 .{ }^{146}$ Loss of a thumb, on the other hand, was worth only $\$ 575.08$, and the severing of a big toe was compensable by payment of merely

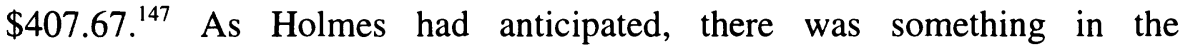
systematic and regularized calculation of the value of human life that distinguished state compensation from the haphazard awards of common law juries and courts.

\section{Industrial War, Industrial Army}

If the analogy between man and machine was a recurring theme in progressive arguments about workmen's compensation, so was the metaphor of industrial war. In analogizing industry to warfare, the supporters of compensation were hardly breaking new ground. ${ }^{148}$ The great strikes of the late nineteenth century had seemed to poise the United States on the brink of a civil war between capital and labor. ${ }^{149}$

For progressive supporters of workmen's compensation, the goal of work accident reform was to turn the trajectory of industrial war outward. The common law, they argued, "breeds antagonism between employers and employees" by setting them in an adversarial relation. ${ }^{150}$ Workmen's compensation, on the other hand, would transform industrial war into a battle waged by workers and industrialists working in concert to push the outer limits of industrial production. ${ }^{151}$ "When our ancestors made war their principal

e.g., New York STATE DEP'T OF Labor, ANNUAl RePORT OF THE INDUSTRIAL COMmiSSION FOR 1918, at 109-10 (1919). By 1917, all but seven states with compensation laws had switched to the New Jersey approach. See 3 COMMONS ET AL., supra note 4, at 603-04; see also, e.g., Workmen's Compensation Law, ch. 816, § 15.3, 1913 N.Y. Laws 2277, 2285.

146. See NEW York STATE DEP'T OF LABOR, ANNUAL REPORT OF THE INDUSTRIAL COMMISSION FOR 1915 , at 130 (1916).

147. See id.

148. See, e.g., KARL MARX \& FrIEDRICH Engels, The Communist Manifesto, in KARL MARX: ThE SELECTED Writings 221, 237 (David McClellan ed., Oxford Univ. Press 1977) (1848).

149. "The state of industrial society is a state of war," wrote social critic Washington Gladden in 1886, "and the engagement is general all along the line." Washington Gladden, Is It Peace or War?, 32 CENTURY Mag. 565, 565 (1886); see also Nell Irvin PainTER, STANDING AT ARMAgeddon 36-71 (1987) (describing late-19th-century fears of an industrial war between the classes); RODGERS, supra note 6, at 34 (same).

150. WAINWRIGHT COMMISSION REPORT, supra note 98 , at 19.

151. See, e.g., DowNEY, supra note 126, at 1 ("Peace has its perils no less than war; work accidents in the aggregate are equivalent to the losses of a perpetual campaign."); Robert W. Bruere, The Welfare War, 1911 HARPER'S MONTHLY 674, 675 (comparing the casualties of industry to those of the Civil War and the American Revolution); Snipped Finger Exhibit, N.Y. TIMES, Dec. 16, 1910, at 2 (quoting Albert R. Shattuck of the Executive Committee of the American Museum of Safety making comparisons between industrial carnage and war). Edward Bellamy's 1888 utopian novel Looking Backward had anticipated the progressive conception of industrial army. In Bellamy's account, a futuristic 20th-century America "applied the principle of universal military service . . to the labor question" and created a national "industrial army." EdWARd BELlamy, LoOKING BACKWARD, 2000-1887, at 57-58 (Signet Classic 1960) (1888). 
business, there was blood," observed William Hard in Everybody's Magazine. ${ }^{152}$ "And when we, their descendants, make industry our principal business, ... there still is blood." 153 The annual loss in industry in New York, it was remarked, amounted to more casualties than any battle of the Revolution or Civil War. ${ }^{154}$ Even future antiwar activist Crystal Eastman resorted to military metaphors: "Extreme caution is as unprofessional among the men in dangerous trades as fear would be in a soldier," she observed. ${ }^{155}$ The difficulty compensation reformers thus confronted was not how to reconcile workers and capitalists so much as how best to compensate "the great army of American wage-earners in all occupations."156

Just as the analogy of worker to machine tacitly conceded control of the workplace to the employer, military metaphors reinforced the hierarchical status relation obtaining between the captains of industry and their industrial foot-soldiers. "It is a maxim of military science," announced August Belmont, chair of the National Civic Federation's Department on Compensation for Industrial Accidents,

that it is the first duty of an officer to look after the welfare of his men and to avail himself of every opportunity to preserve the military unit from injury or destruction. There is an analogy between this duty of the military officer toward the soldiers of his command and the obligation of the employer, who bears a similarly responsible relation to the welfare of the wage earners who fill the rank and file of the voluntary armies of industry. ${ }^{157}$

For Belmont, as for others who saw in the condition of industrial workers parallels to soldiers in battle, compensating workers for work accidents was part of the broader reorganization of work that entailed increasingly stark relations of duty and command in the workplace.

\section{Transforming the Social Meaning of Work}

As we have seen, a wide array of nineteenth-century Americans believed that work had a morally beneficial effect on those who toiled. ${ }^{158}$ From the perspective of the worker, this work ethic was a double-edged sword. If the

152. Hard, supra note 141 , at 361 .

153. Id. at 362.

154. See Bruere, supra note 151, at 675 ; $c f$. DowNEY, supra note 126 , at 1 ("The toll of life and limb exacted by American industries during the second decade of the twentieth century exceeds the nation's losses in battle from the Declaration of Independence to the present day.").

155. EASTMAN, supra note 98 , at 93-94.

156. PHELPS, supra note 91, at 2; see also Chauncey B. Brewster, Industrial War or Peace, 70 INDEPENDENT 1417, 1417 (1911) (advocating for employers' liability reform in order to eliminate the "state of continual war between capital and labor").

157. Reward for Injured in All Industries, N.Y. TIMES, Dec. 23, 1910, at 2.

158. See supra Section I.B. 
idea that work had intrinsic value could be a source of dignity for workers, it could also be a tool for employers seeking to enforce labor discipline in exploitative work situations. But the idea that work could be intrinsically rewarding was wholly absent from the workmen's compensation debates. Workmen's compensation supporters conceived of work as accruing not to the benefit of the worker but to employers or to the public. ${ }^{159}$ The worker benefited from the process of production not as a worker but only insofar as he might count himself as a member of the consuming public. Work, in short, was no longer thought to be important for its own sake.

Workmen's compensation reflected changes in the ideology of work as much as, or even more than, it created them. Late nineteenth- and earlytwentieth-century capitalism had removed much of work's morally constitutive characteristics wholly independently of work accident law. Yet the impact of workmen's compensation should not be underestimated. In the enactment of workmen's compensation, middle- and upper-class reformers signaled their abandonment of the conceptual link between work and moral virtue and thus legitimated and accelerated the extension of managerial control in the workplace; if management paid for workplace accidents, the argument for managerial control was that much stronger.

\section{LABOR AND WORKMEN'S COMPENSATION REFORM}

Workmen's compensation posed a difficult problem for workers and unions. It offered workers and their families a material resource to cope with work injuries and deaths. But it was advanced in a language of efficiency that threatened to routinize and legitimize increased managerial control of the workplace. Workers ultimately supported workmen's compensation programs; from a pragmatic perspective, the promise of state insurance against industrial accidents was simply too great for workers to refuse. In their halting support for workmen's compensation reform, however, labor was obliged tacitly to compromise the ideals of dignity and discretion in work processes that had been at the heart of the nineteenth-century labor movement.

\section{A. Employer Fault and the Dilemma of No-Fault Insurance}

Workers were hardly unaware of the implications of compensation plans for control over the processes of production. By the 1900s, workers had gained considerable experience with the private compensation plans that large employers began to put in place beginning in the late 1860s and 1870s, plans

159. " $[I] f$ the instrumentality through which the injury is caused be conducted primarily for the benefit of the individual" who employs the injured party, announced one lawyer, "it is not arbitrary, but reasonable and just, if he be made to indemnify the injured person." LORD, supra note 124, at 13. 
that were designed in large part to extend management's control over the workplace by undermining workers' trade union affiliations and increasing the costs of quitting. ${ }^{160}$

When workers began in the last third of the nineteenth century to militate for a liberalized law of workplace accidents, they pushed for the abolition of the employers' defenses of fellow servant and assumption of risk rather than no-fault compensation. ${ }^{161}$ State federations of workingmen supported this type of employers' liability legislation through the final two decades of the nineteenth century. ${ }^{162}$

In championing employers' liability legislation, workers and their unions sought to establish a principled compromise with the ideal of worker selfcontrol by emphasizing the idea of blame. In one sense, union support for employers' liability reform pushed unions to abandon the notion that work in and of itself was a distinctively important activity in the constitution of an independent and self-disciplined citizenry: Workers, the unions argued, ought to be on the same footing before the law as passengers. ${ }^{163}$ But in their advocacy of liberalized liability rules, workers emphasized the social condemnation and assignment of fault that accompanied the common law negligence principle. ${ }^{164}$ In the common law trial, the adjudication of work accident claims allowed juries of an injured worker's peers to announce the responsibility and fault of the employer. ${ }^{165}$

No such middle ground was available for no-fault workmen's compensation. No-fault compensation plans smacked of the relief funds run privately by employers, schemes that had been designed to undermine worker control and worker organizations. ${ }^{166}$ Moreover, compensation replaced the

160. See Asher, supra note 74 , at 21-25.

161. See INDEPENDENT ORder OF KNIGHTS OF LABOR, DECLARATION OF PRINCIPLES (1896); Political Programme, 1 AM. FEDERATIONIST 203 (1894); Edward W. Searing, Employers' Liability Law, 1 AM. FEDERATIONIST 93, 94-95 (1894).

162. See, e.g., Philip Taft, Labor Politics American Style: The California State Federation OF LABOR 44 (1968).

163. See, e.g., New York Legislature Enacts Employers' Liability Law, 41 LOCOMOTIVE FIREMEN'S MAG. 84, 85-86 (1906). By adopting the analogy of the worker to the passenger, workers presaged the 20 th-century labor movement's abandonment of the distinctively 19th-century view that production was qualitatively different from consumption.

164. The National Labor Union's first call for employers' liability reform in 1868, for example, announced that "it is a notorious fact that fatal so-called accidents have frequently occurred through a culpable, if not criminal, disregard or neglect of employers generally for the protection of human life." 9 DOCUMENTARY HISTORY, supra note 79, at 223-24. See also GEORGE E. MCNEILL ET AL., THE LABOR Movement 490 (George E. McNeill ed., Boston, A.M. Bridgman \& Co. 1887) (decrying the "scandal" that a man "must be pauperized" after work accidents and advocating employers' liability reform).

165. To be sure, in cases in which the injury was the result of a fellow servant's negligence, the liability of the employer would only be vicarious and thus the immediacy of the employer's fault would be somewhat attenuated. Yet jury verdicts were widely understood to pit sympathetic pools of a worker's peers against employers. See, e.g., Launcelot Packer, The Hazards of Industry: Should the Workman Bear the Whole Burden?, 1909 OUTLOOK 319, 320-21.

166. See A. Maurice Low, Shifting the Burden-Compensation for Injuries, 186 N. AM. REV. 651,655 (1907) (observing that at least some workers opposed workmen's compensation out of fear that compensation would eventually come out of the workers' own pockets). 
assignment of fault with a system that threatened to rationalize industrial accidents and substitute professionalized administration without regard to fault for jury trial on the question of culpability. Finally, compensation schemes appeared to impose a state-sponsored paternalism for the paternalism of the employer. ${ }^{167}$ Thus, "sore and sad" as American Federation of Labor leader Samuel Gompers was as a result of the "killing, the maiming of so many of [his] fellow workers," he sought to effect "their own emancipation through their own efforts." 168

As a result of worker suspicion of state-sponsored no-fault insurance schemes, compensation remained a middle- to upper-class reform throughout the first decade of the twentieth century. ${ }^{169}$ Labor's opposition to progressive compensation schemes remained strong in some sectors as late as 1910. When the United States Brewers' Association organized a comprehensive, industrywide relief fund with the aid of progressive reformers, rank-and-file workers bitterly opposed the plan in favor of an insurance system run by the workers themselves. ${ }^{170}$

The difficulty with workers' persistent opposition to workmen's compensation was that their own employers' liability reform proposals met with little success. Unions repeatedly found their proposals buried in legislative committees and simply never acted on. ${ }^{171}$ When legislatures did enact reform legislation, more often than not it was weakened by exceptions to the very exceptions it enacted and then further weakened by narrow judicial construction. ${ }^{172}$ Unable to enact their own liability reform program and confronted with the fact that only twenty-five percent of all industrial accidents were resulting in payments from the employer to the employee, many workers turned to workmen's compensation. ${ }^{173}$

167. See, e.g., Eva McDonald-Valesh, Conditions of Labor in Europe, 3 AM. FEDERATIONIST 111,113 (1896) (warning of the antiunion design of "paternal" social insurance schemes).

168. Gary M. Fink, The Rejection of Voluntarism, 26 INDUS. \& LAB. REL. REv. 805, 811 (1973) (quoting Gompers) (citation omitted).

169. See Robert F. Wesser, Conflict and Compromise: The Workmen's Compensation Movement in New York, 1890s-1913, 11 LAB. HIST. 345, 351 (1971). When the New York Social Reform Club proposed the first American compensation legislation in 1898, the Workingmen's Federation of the State of New York opposed the legislation, offering instead its own employers' liability law designed to preserve the common law framework. See IRWIN YELLOWITZ, LABOR AND THE PROGRESSIVE MOVEMENT IN NEW YORK STATE, 1897-1916, at 107-08 (1965). Robert Asher attributes labor's slow adoption of workmen's compensation to its ignorance of the details of European-style social insurance. See Robert Asher, Business and Workers' Welfare in the Progressive Era: Workmen's Compensation Reform in Massachusetts, 18801911, 43 BuS. HIST. REV. 452, 457 (1969). Labor leader George McNeill, however, had provided a lengthy description of European social insurance legislation, including the German workmen's compensation program, in his important 1887 book The Labor Movement. See MCNEILL ET AL., supra note 164, at 58.

170. See Nuala McGann Drescher, The Workmen's Compensation and Pension Proposal in the Brewing Industry, 1910-1912: A Case Study in Conflicting Self-Interest, 24 INDUS. \& LAB. REL. REV. 32, 42-43 (1970).

171. Asher convincingly attributes labor's failure to get such legislation enacted to the labor movement's primitive and decentralized lobbying organizations. See Asher, supra note 79, at 205.

172. See id. at 208-15.

173. See Yellowitz, supra note 169, at 109-10. 


\section{B. The Ambiguities of Worker Acceptance}

Labor began to shift toward support for workmen's compensation around 1909. ${ }^{174}$ Acceptance of and support for compensation was halting even then. ${ }^{175}$ Some workers, for example, supported a regime of criminal sanctions against employers for injuries to their employees. ${ }^{176}$ Nonetheless, the trend toward support for workmen's compensation was clear, and nowhere more so than in the hearings held by the Wainwright Commission across New York State in 1909. The overwhelming majority of the labor representatives before the Commission stated their support for the principle of workmen's compensation. As one Brooklyn labor representative testified, "[T] he attitude of our organizations is going rapidly towards compensation rather than improvement in the present law."177 Or as a representative of the Metal Polishers and Buffers Union reported of workers in Rochester, "The sentiment is that we are in favor of it, to have a compensation act."178

Under New York's 1910 workmen's compensation bill, injured employees had the option of either suing under a liberalized common law absent the nineteenth-century employer defenses, or getting no-fault compensation. ${ }^{179}$ Workers' support for the act was thus understandable since they sacrificed little. Nonetheless, in turning to compensation, workers adopted (as progressives had before them) a language that reaffirmed employer control in the workplace and tacitly conceded workers' lack of agency. "The injured workman is just as much an incident of the modern factory, as is the damaged machine," wrote the United Brotherhood of Carpenters and Joiners in its brief to the Wainwright Commission. ${ }^{180}$ "Both are proper items of operating expense, and should come out of the employers' profits." ${ }^{181}$ The secretary of the International Brotherhood of Electric Workers argued that " $[\mathrm{t}] \mathrm{he}$ disability

174. See id.

175. See, e.g., CONFEREnCE of Commissions, supra note 96, at 13-14 (discussing "foolish" but widespread opposition to compensation legislation among workers in Illinois in 1910). Gompers was curiously fatalistic about compensation reform, see Courts Usurp Power Declares Gompers, N.Y. TIMES, Nov. 15, 1910, at 3, but he saw compensation as a way of prompting employers to make safety reforms in the workplace, see MINUTES OF EVIDENCE ACCOMPANYING THE FIRST REPORT TO THE LEGISLATURE OF THE STATE OF NEW YORK BY THE COMMISSION APPOINTED UNDER CHAPTER 518 OF THE LAWS OF 1909 TO INQUIRE INTO THE QUESTION OF EMPLOYERS' LIABILITY AND OTHER MATTERS 92-94 (1910) [hereinafter WAINWRIGHT COMMISSION HEARINGS].

176. See, e.g., WAINWRight COMMISSION HEARINGS, supra note 175, at 104-05; WaINWRight COMMISSION REPORT, supra note 98, at 143.

177. WaINWRight COMmission HearingS, supra note 175, at 102 (statement of James Boyle of the Brooklyn Central Labor Union).

178. Id. at 219-20 (testimony of Sylvester P. Gartland of the Metal Polishers and Buffers Union of Rochester). Representatives of union locals indicated that workers had discussed the issue of compensation among themselves for months. See, e.g., id. at 219.

179. See An Act To Amend the Labor Law, in Relation to Workmen's Compensation in Certain Dangerous Employments, ch. 674, § 218, 1910 N.Y. Laws 1945, 1947.

180. WAINWRIGHT COMMISSION REPORT, supra note 98, at 133 (quoting brief of the United Brotherhood of Carpenters and Joiners).

181. Id. 
of the worker is an analogous thing to the breaking down of a machine, and should ... be included in the regular charges of the business." 182 Gompers was driven to adopt the idea that workers, like machines, were the responsibility of employers: "Industry must bear the financial burden of accidents to the human being, exactly as it does now in case of accidents to machinery or to other property." 183 "[T] Commission, "that labor is becoming so divided and sub-divided and specialized, that the workman has simply to become a part of the machine and the opportunity for him to demonstrate his individuality and capacity and intelligence is passing by very very fast." 184

Like progressive arguments for compensation, labor's language of reform conceded that work itself had little intrinsic value. Work functioned solely to produce profits for the employer. James J. Waters of the Marine Engineers Beneficial Association of Brooklyn testified that "accidents in a large proportion of industrial employments are incidental to the business and just as much a part of the cost and the result for which the business is organized and conducted, as labor or material used in the business." ${ }^{185}$ For Waters, the worker had become a part of the employer's business, an incident of production much like the material and equipment of the employer. Moreover, that business operated solely for the benefit of the employer, not the worker. Indeed, Waters's argument tracked the views that had been articulated to the Commission by John White, vice president of the New York Edison Company: The "expense" of workplace accidents, White wrote to the Commission, "should in the first instance be borne solely by the employer as one of the items in his manufacturing costs." 186

Opposition to the commodification of human labor lay at the center of the labor movement in the first decades of the twentieth century. ${ }^{187}$ Thus, when labor succeeded in 1914 in having the Clayton Act passed, with its abstract declaration that "the labor of a human being is not a commodity or article of commerce," ${ }^{188}$ Gompers announced that the Act was nothing less than the "Magna Carta" of American labor. ${ }^{189}$ Yet even as labor was succeeding in the enactment of the Clayton Act, workmen's compensation debates put labor

182. Id. (quoting a letter from the secretary of the International Brotherhood of Electrical Workers, Local 277, Kingston, N.Y.).

183. Courts Usurp Power Declares Gompers, supra note 175.

184. WaINWRight Commission HEARINGS, supra note 175, at 94 (statement of Samuel Gompers). "That," responded Commissioner John Cotton, "is one of the reasons for paying for his legs and arms when they come off-I mean that particular tendency that tries to treat him as a machine when you are paying for it?" Id.

185. WAINWRIGHT COMMISSION REPORT, supra note 98, at 118 (statement of James J. Waters).

186. Id. at 130 (quoting a letter from John White).

187. See William E. Forbath, Law and the Shaping of The AmERican Labor Movement $155-$ 66 (1991); James Gray Pope, Labor's Constitution of Freedom, 106 YALE L.J. 941, 984-86 (1997).

188. Ch. 323, § 6, 38 Stat. 730, 731 (1914) (codified as amended at 15 U.S.C. $\$ 17$ (1994)).

189. Samuel Gompers, The Charter of Industrial Freedom, 21 AM. FEDERATIONIST 971, 972 (1914). 
in the paradoxical position of affirming its status as a factor of production. Workmen's compensation legislation, to be sure, promised to create a new degree of material security for American workers. But by tacitly conceding control over and responsibility for the workplace to the employer, the language of workmen's compensation reform compromised labor's resistance to conceiving of work and workers as mere commodities.

\section{CONCLUSION: BRANDEIS'S JURY OF WORKMEN}

This Note has sought to show that the transformation of work accident law reflected and gave shape to the changing ways in which Americans thought about and organized work. This is not to say that the extension of liability necessarily and inevitably required a sacrifice in workers' relative autonomy in the process of production. In the abstract, workmen's compensation legislation could have offered working Americans a renewed participation in the conditions of production. Indeed, some viewed workmen's compensation as reconfiguring on a larger scale the self-help organizations that late nineteenth-century workers had created to insure against accidents. ${ }^{190}$ Yet the ambiguity of workmen's compensation was that, set as it was in the context of an early-twentieth-century world of scientific management, it both reflected and reproduced the degradation of work in theory and in practice.

This was not the only road that workmen's compensation reform could have taken. For Louis D. Brandeis, the agitation to reform work accident law reflected a more general need to develop innovative ways to reconstruct worker participation in the control of their working lives. ${ }^{191}$ Brandeis sought to resolve the dilemma of work accident law by developing a new institutional framework in which workers would participate in the governance of the workplace. ${ }^{192}$ According to Brandeis, workers and employers ought to participate in accident prevention and compensation on an equal basis. ${ }^{193}$ Accordingly, he proposed "to secure the fullest cooperation of employer and employee" in a system of accident compensation and prevention that would merge the efficiency of compensation with worker participation in the governance of the workplace. ${ }^{194}$ At the core of Brandeis's joint employer-

190. See, e.g., HENDERSON, supra note 121 , at 10 (describing state insurance as "an act of social cooperation on the part of the entire community").

191. Worker organizations, despite their adoption of a language that potentially undermined some of their broader aims, also sought to find new institutional solutions to worker participation in the governance of work. Union representatives argued that through collective action workers would be able to maintain a modicum of control over the workplace. See, e.g., WAINWRIGHT COMMISSION HEARINGS, supra note 175, at 109 (statement of Charles Burns, Secretary of the Board of Delegates of the Building Trades of Brooklyn) (arguing that union representation was critical to reducing the toll of work accidents).

192. See Louis D. Brandeis, From the Standpoint of the Lawyer, in INJURED IN THE COURSE OF DUTY 113, 114-15 (William Hard et al. eds., 1910).

193. See id. at 114.

194. Id. 
employee scheme of workplace accident regulation was a proposal for "juries of workmen." 195 Compensation to the injured worker was to be automatic, but the jury of workmen would independently inquire into the causes of the accident. It would call witnesses and hear evidence in a public forum, in the presence of as many workmen "as c[ould] conveniently attend without unduly interfering with their work." ${ }^{196}$ As a final step in Brandeis's proposal for a "Cooperative Accident Insurance Law," the jury of workmen would decide who was to "blame" for the accident. ${ }^{197}$

Brandeis's views appear to have attracted little support. Once workers had accepted the principle of workmen's compensation, they were extremely reluctant to accept plans that included employee contributions to an accident insurance fund. Employers, on the other hand, were presumably loathe to allow workers within the firm to organize into bodies empowered to assign blame to the company in cases of worker injuries. Unlike the workmen's compensation legislation that states enacted beginning in 1910, however, Brandeis's proposal for juries of workmen found a place for worker participation in the governance of work even within the world of a large-scale industrial economy. 